ROCZNIKI KULTUROZNAWCZE

Tom/Vol. XI, numer/number 4 - 2020

DOI: http://doi.org/10.18290/rkult20114-4

WANDA BAJOR

MAŁGORZATA GRUCHOŁA

\title{
MIT „CIEMNEGO” ŚREDNIOWIECZA WE WSPÓŁCZESNYM DYSKURSIE SPOŁECZNYM
}

Léopold Génicot, pisząc w 1964 r. o następowaniu po sobie kolejnych okresów historycznych, w odniesieniu do kultury średniowiecznej stwierdził: „Dzieła, sztuka, pojęcia, idee, społeczności - wykute i stworzone w średniowieczu, przetrwały do dziś i nic nie zapowiada ich zmierzchu" Dziś, po sześćdziesięciu latach ta konstatacja nie wydaje się oczywista i powstaje pytanie: czy na pewno wymienione fenomeny kulturowe są nieprzemijające? Czy trwają „wykute” w kamieniu, nie poddając się niszczycielskim siłom upływającego czasu i zdarzeń? Nasuwa się w tym kontekście skojarzenie z tytułami książek współczesnych intelektualistów, analizujących $\mathrm{w}$ ponurym tonie obecny stan kulturowy, jak np. amerykańskiego polityka Patricka J. Buchanana Śmierć Zachodu. Jak wymierajace populacje i inwazje imigrantów zagrażaja naszemu krajowi i naszej cywilizacji lub francuskiej politolog Thérèse Delpech Powrót barbarzyństwa wXXI wieku²; wydają się

Dr hab. WANDA BAJOR, prof. KUL — Katolicki Uniwersytet Lubelski Jana Pawła II, Wydział Filozofii, Instytut Filozofii, Katedra Historii Filozofii w Polsce; e-mail: bajor@kul.lublin.pl; ORCID: https://orcid.org/0000-0003-2121-0608.

Dr hab. MaŁgorzata GruchoŁa, prof. KUL — Katolicki Uniwersytet Lubelski Jana Pawła II, Wydział Nauk Społecznych; Instytut Dziennikarstwa i Zarządzania; Katedra Komunikacji Wizualnej i Nowych Mediów; e-mail: malgorzata.gruchola@kul.pl; ORCID: https://orcid.org/0000-0002-2367-0416.

${ }^{1}$ Léopold GÉNICOT, Powstaje nowy świat, przeł. Jan Stanisław Łoś (Warszawa: Ossolineum, 1964), 259.

${ }^{2}$ Patrick J. Buchanan, Śmierć Zachodu. Jak wymierające populacje i inwazje imigrantów zagrażaja naszemu krajowi i naszej cywilizacji, przeł. Jan Przybył, Danuta Konik i Jerzy Morka (Wrocław: Wydawnictwo Wektory, 2006); oryg. Death of the West: How Dying Populations and Immigrant Invasions Imperil Our Country and Civilization (New York: St. Martin's Press, 2002); Thérèse DeLPECH, Powrót barbarzyństwa w XXI wieku, przeł. Wiktor Dłuski (Warszawa: Media Lazar Nadir, 2008); oryg. L'Ensauvagement: Essai sur le retour de la barbarie au XXI siècle (Paris, Grasset/Fasquelle, 2005). 
oni zaprzeczać optymizmowi swego poprzednika. Co więcej, gdy oglądamy w mediach obrazy roztrzaskiwanych buldożerami kamiennych gotyckich katedr w zachodniej Europie, sprawa wydaje się przesądzona. Do rangi wymownego znaku dla całego świata urósł spektakularny pożar w 2019 r. paryskiej katedry Notre Dame (zbudowanej w XII-XIV wieku), wydawało się nieprzemijającego symbolu europejskiej Christianitas. Cały świat patrzył $\mathrm{z}$ przejęciem na ten smutny spektak1, jak na ginącą w płomieniach alegorię współczesnej cywilizacji europejskiej, jak na obraz chaosu ogarniającego dzisiejszy świat. Na naszych oczach ogień trawił dzieło zawierające „wszystko, co piękne, poetyckie i czarujące w średniowiecznym francuskim duchu". Sam prezydent Francji Emmanuel Macron wyznał wówczas, że „płonie symbol naszej tożsamości”, chociaż Francja już dawno wyrzekła się chrześcijaństwa, a tę samą katedrę tylko cudem uratowano przed unicestwieniem przez osiemnastowiecznych, oświeconych rewolucjonistów ${ }^{3}$. Czy wobec tego możemy stwierdzić, że Génicot, wypowiadając swą optymistyczną tezę o trwałości dzieł średniowiecza, gorzko się mylił?

Z drugiej strony możemy zapytać, czy jakakolwiek kultura, a w tym wypadku kultura średniowieczna, niezależnie od zniszczeń i przemijalności jej materialnych nośników, może przetrwać i odrodzić się, jak kiedyś antyk odradzał się w różnych renesansach z gruzów rzymskiego imperium. Czy, jak chciał Génicot, przetrwają stworzone przez nią pojęcia i idee? Te bowiem jako byty niematerialne wydają się być trwałe i nieprzemijające. Ci (wydaje się nieliczni), którzy znają wartość średniowiecza i są świadomi doniosłości dorobku kulturowego tej epoki, mogą patrzeć w jej stronę z nadzieją, że Europa ma swe głębokie korzenie, w których tkwią ożywcze soki i dzięki nim może się odrodzić, może na nowo odkryć niewyczerpane źródła swego rozwoju i twórczości. Tę filozoficzną prawdę wyraził językiem baśni Antoine de Saint Exupéry w Małym Księciu: gdy tytułowy bohater pyta napotkanego

\footnotetext{
${ }^{3}$ Miała podzielić los innych piętnastu zburzonych paryskich kościołów, lecz uratował ją pewien naukowiec, który przekonał rewolucjonistów, żeby zachować tę budowlę, bo wcześniej w tym miejscu znajdowała się świątynia egipskiej bogini Izydy. Natomiast w 2013 r. katedrę Notre Dame wybrał za świadka swego samobójstwa-protestu historyk Dominique Venner, choć niewierzący, chciał w ten sposób wykrzyczeć swój sprzeciw wobec niszczenia rodziny, prawnego zrównaniu związków jednopłciowych z naturalnymi rodzinami, multikulturalizmowi, islamizacji i utracie tożsamości przez francuski naród. W liście pożegnalnym napisał: „Oddaję to, co pozostało mi z życia, by zaprotestować. Wybrałem symboliczne miejsce — katedrę Notre Dame w Paryżu, którą szanuję i podziwiam, została zbudowana za sprawą geniuszu moich przodków [...]”. Cyt. za: Grzegorz GóRNY, „Pożar Notre Dame: znak do odczytania”. „Niedziela” (ogólnopolska) 2019, nr 17: 6-8. Niedziela.pl, dostęp 22 lutego 2021, https://www.niedziela.pl/artykul/142506/nd/Pozar-NotreDame-znak-do-odczytania.
} 
na pustyni kwiatu, gdzie są ludzie, ten mu odpowiada: „Widziałem ich przed laty. Lecz nigdy nie wiadomo, gdzie można ich odnaleźć. Wiatr nimi miota. Nie mają korzeni — to im bardzo przeszkadza"

„To im bardzo przeszkadza” - dlaczego? Odpowiedź jest jedna: człowiek bez duchowych korzeni, bez zakotwiczenia w hierarchii wartości, bez kulturowej i duchowej tożsamości staje się bezwolną marionetką miotaną przez najróżniejsze wiatry propagandy i wichury ideologiczne. Bez określonego systemu obiektywnych wartości brakuje kryterium do odróżniania prawdy od fałszu, dobra od zła, piękna od brzydoty. W ten sposób człowiek daje się łatwo manipulować i nawet sobie nie uświadamia, że traci wolność, idąc bezkrytycznie za tym, co podaje mu się do wierzenia. Pisze o tym Thérèse Delpech, stwierdzając, że jedną z najbardziej zastanawiających cech epoki informatycznej jest łatwowierność ${ }^{5}$. W obecnej postmodernistycznej rzeczywistości, z szalejącą dekonstrukcją, człowiek, odrzucając uznane w tradycji prawdziwe autorytety, bezrefleksyjnie ulega pseudoautorytetom w postaci różnych celebrytów i wszelkiej maści guru. Oni jednak zamiast mądrości, która wskazałaby prawdę o sensie i celu życia, mają do zaproponowania jedynie różne odmiany hedonizmu, który ostatecznie prowadzi do nihilizmu i rozpaczy. W imię fałszywie pojmowanej wolności człowiek odrywa się od swoich kulturowych „korzeni”, bez których traci oparcie dla stabilnego rozwoju i w efekcie usycha w duchowej pustce, ludzkość bowiem już dawno doświadczyła, że żadne dobra materialne, choćby najwyższej próby, nie są w stanie zaspokoić ludzkiego pragnienia szczęścia ${ }^{6}$.

W refleksji na temat europejskiej tożsamości kulturowej odwołujemy się do trzech jej źródeł: filozofii greckiej, prawa rzymskiego i chrześcijaństwa. Jeśli chodzi o trzecie źródło, czyli chrześcijaństwo, to właśnie związana z nim kultura średniowieczna budowała Europę w oparciu o ewangeliczne wartości, takie jak: prawda, miłość, współczucie, pokora, równość, braterstwo, wolność, godność osoby ludzkiej.

\footnotetext{
${ }^{4}$ Antoine de SAINT-EXUPÉRY, Mały Książę, przeł. Jan Szwykowski (Warszawa: Instytut Wydawniczy Pax, 1971), 55.

${ }^{5}$ Por. DelPeCh, Powrót barbarzyństwa, 57.

${ }^{6}$ Możemy posłużyć się przykładem choćby starożytnej szkoły cyrenaików, którzy głosili skrajny hedonizm. Ich zdaniem szczęście miało polegać na sumie przyjemności, niezależnie od ich jakości, liczy się ilość przeżytych przyjemności. Szybko jednak doświadczyli, że tak pojęta przyjemność nie daje człowiekowi szczęścia, wobec czego modyfikowali ten pogląd, a Hegezjasz doszedł do przekonania, że skoro nie można osiągnąć postulowanego szczęścia, to nie warto żyć, i nawoływał do śmierci. I tak od hedonizmu doszli do nihilizmu. Por. Władysław TATARKIEWICZ, Historia filozofii, t. 1: Filozofia starożytna i średniowieczna (Warszawa: Państwowe Wydawnictwo Naukowe, 1970), 70 .
} 
Możemy zapytać, czy podobnie jak ongiś średniowiecze rozwijało się w różnych fazach odradzanego dziedzictwa twórców antyku, epoka współczesna może być zdolna do takich renesansów w oparciu o skarby duchowe wieków średnich. Czy dla współczesnego człowieka średniowiecze może stać się inspiracją i punktem odniesienia w poszukiwaniu utraconej tożsamości, w odbudowywaniu kultury, w kreowaniu swego stylu życia?

Jest jedna ku temu poważna przeszkoda. Oto bowiem licząca około tysiąca lat epoka średniowieczna jest, jak żadna inna, ciągle deprecjonowana i ignorowana. Powstały wieki temu mit, stereotyp „ciemnego” średniowiecza utrwalił się w powszechnym dyskursie i wydaje się, że zajął stałe miejsce w potocznej świadomości. Mediewiści stawiają sobie pytanie, dlaczego tak się dzieje. Dlaczego, mimo prawie już dwustuletniej pracy badawczej, od kiedy narodziła się mediewistyka, opracowująca spuściznę intelektualną tej epoki, nie udało się pokonać mitu „ciemnego” średniowiecza? Możemy bowiem dziś usłyszeć $\mathrm{w}$ mediach, i nie tylko, z ust wydawałoby się ludzi wykształconych, jak dziennikarze, politycy, nauczyciele, którzy jakąkolwiek negatywną ocenę danego zjawiska kwitują bezrefleksyjnie epitetem: „ciemne” średniowiecze. I słyszymy to $\mathrm{z}$ różnych stron, niezależnie od opcji politycznych lub światopoglądowych.

Jest takie zjawisko w kulturze, które polega na tym, że pewne stereotypy, mity i fikcje, niemające nic wspólnego z obiektywną rzeczywistością, trwają niezmiennie, mimo że prawda historyczna poddała je oczywistej falsyfikacji. Funkcjonowanie mitu w kulturze jest tak silne, że ulegają mu wszyscy, także ludzie wykształceni, i trudno z nim walczyć. Problematykę związaną z mitem „ciemnego" średniowiecza podejmuje mediewista Stanisław Wielgus, który w rozdziale swojej książki, zatytułowanym „O micie «ciemnego» średniowiecza i «światłej» nowożytności polemicznie”, zastanawia się nad genezą $\mathrm{i}$ obecnością $\mathrm{w}$ kulturze tego zjawiska ${ }^{7}$. Wylicza przyczyny, które spowodowały tak wrogą postawę wobec epoki średniowiecza, postawę przenoszoną przez kolejne wieki jak w sztafecie, aż do współczesności. Historycy są zgodni co do tego, że dobre imię średniowiecza zepsuli ludzie odrodzenia. W odrodzeniu potępiano w czambuł wszystko, co było w poprzedniej epoce, a wynoszono wszystko, co było w starożytności. Przykładem może być zupełnie niezrozumiałe deprecjonowanie sztuki średniowiecznej, którą twórcy renesansu określili mianem „dzikiej” — „gotyckiej”, będącej - ich zdaniem - wytworem barbarzyńskich Gotów. A przecież za-

\footnotetext{
${ }^{7}$ Por. Stanisław Wielgus, $Z$ badań nad średniowieczem (Lublin: Redakcja Wydawnictw KUL, 1995).
} 
chwycamy się monumentalnymi, strzelistymi katedrami czy wspaniałym malarstwem średniowiecznym, podziwiając kunszt ówczesnych twórców. Także pismo zreformowane w IX wieku było tak piękne, że ludzie renesansu nie uwierzyli, by mogło powstać w pogardzanej przez nich epoce, i przypisali je antykowi. Takie pogardliwe myślenie oddaje sam, ukuty w Anglii, termin „the dark ages”, odnoszący się do wieków średnich. Jak podkreśla Stanisław Wielgus, kolejna przyczyna deprecjonowania średniowiecza leży w fakcie, że był to czas, gdy Europa stanowiła jedność cywilizacyjną, rodzaj rzeczypospolitej chrześcijańskiej. Cała kultura miała inspirowany chrześcijaństwem wymiar religijny, instytucjonalnie tworzył ją Kościół (w sferze nauki, sztuki, opieki społecznej, medycyny etc.), i każdy, kto uważał się za wroga Kościoła, stawał się tym samym wrogiem tworzonej przez niego kultury. Szczególnie inteligencja protestancka swoją wrogość do Kościoła przenosiła na całą epokę średniowieczną. Dalej tę deprecjację kultury średniowiecza pogłębiło oświecenie, pojmujące siebie jako całkowite zerwanie ze starym „złym” światem. Stąd też wrogość do religii, zwłaszcza chrześcijańskiej, którą trzeba bezwzględnie zwalczać jako źródło wszelkich nieszczęść. Kościół uważano za ostoję ciemnoty i zabobonu, hamującą drogę do postępu, i ciemiężcę ludzi dążących do wolności. Dzieła tego „wyzwolenia” na Zachodzie dokonała rewolucja francuska, a później na Wschodzie rewolucja marksistowska w Rosji; obie, obiecując wyzwolenie, przyniosły anarchię, tyranię i krwawy terror, eksterminując tych, których uznano za zacofanych, nierozumiejących nowoczesnych idei ${ }^{8}$. Jan Paweł II, wskazując $z$ jednej strony na dobre owoce oświecenia, jednocześnie stwierdził, że prawdziwy „kulturowy dramat”, jaki trwa do dziś, to przeciwstawienie chrześcijaństwu tych wartości (wolność, równość, braterstwo), które należą do jego istoty ${ }^{9}$. Wrogość wobec kultury średniowiecznej kontynuowali i z przekonaniem ją zwalczali pozytywiści, scjentyści i materialiści z hasłem Marksa „religia opium dla ludzi”. Hasła antyreligijne i antykatolickie niejako mechanicznie łączyły się z hasłami antyśredniowiecznymi. Kolejną woltą przeciwko wszystkiemu, co reprezentuje kultura średniowiecza, a więc dyscyplinie, porządkowi i hierarchii, jest rozpoczęta w 1968 r. rewolucja kulturowa, z sukcesem przeprowadzana do dziś; jej celem jest „wyzwolenie” człowieka $z$,opresyjnych” tradycyjnych struktur, instytucji społecznych i wartości chrześcijańskimi na czele ${ }^{10}$.

\footnotetext{
${ }^{8}$ Zob. Chantal Delsol, Nienawiść do świata. Totalitaryzmy i ponowoczesnośćc, przeł. Marek Chojnacki (Warszawa: Instytut Wydawniczy Pax, 2017), 39-46.

${ }^{9}$ Por. Jan PAweŁ II, Pamięć i tożsamość. Rozmowy na przełomie tysiącleci (Kraków: Wydawnictwo Znak, 2005), 101-102.

${ }^{10}$ Współczesny filozof brytyjski Roger Scruton, który analizuje fałszywie pojmowaną, absoluty-
} 
W Polsce przykładem kuriozalnego braku obiektywizmu w odniesieniu do dorobku epoki średniowiecza i jego zwalczania może być wydana w PRL książka Mroki średniowiecza, w której prześcigają się ignorancja naukowa z wrogością do religii, a odwoływali się do niej liczni należący do ,autorytetów” budowniczowie „świetlanej” komunistycznej przyszłości ${ }^{11}$. Na takich tekstach budowana jest wizja średniowiecza pokutująca do dziś, także niestety w szkolnych podręcznikach (kim są ich autorzy?) i co za tym idzie - w wypowiedziach nauczycieli.

Szesnastowieczna krytyka średniowiecza, która zerwała ciągłość między umysłowością europejską a kulturą średniowiecza, uniemożliwiła tym samym naturalny kontakt z jej dziedzictwem. Tymczasem twórcy każdej epoki dodają kolejne piętra do istniejącej budowli. Podobnie czynili też ludzie czasów nowożytnych, opierając się na dokonaniach ludzi średniowiecza, tyle że nie chcą się do tego przyznać.

Podkreśla się zwłaszcza rolę średniowiecznej nauki zwanej scholastyką ${ }^{12}$. Dała ona nowożytności zaprawę w myśleniu racjonalnym, od którego zależały wszystkie jej dalsze osiągnięcia. Śmiało można stwierdzić, że scholastyka nauczyła Europę myśleć. Scholastycy rozwinęli dialektykę, czyli zespół metod postępowania, które przedmiot wiedzy formułują w postaci problemu, wykładają go, definiują, wyjaśniają, bronią przed zarzutami, rozwiązują i przekonują słuchacza lub czytelnika. Są to narzędzia badawcze, którymi posługujemy się do dziś, nawet nie wiedząc, komu je zawdzięczamy. W tej metodzie zmierzano do precyzji, ćwiczono ostrość myślenia i wyrażania się, uczono łatwości formułowania myśli i zdolności oddzielania prawdy od fałszu. Dlatego też, jeśli za kryterium naukowości i duchowego oświecenia, przeciwnego ciemnocie, przyjmiemy posługiwanie się rozumem, to scholastyka będzie zawsze górą. Jej cechą wyróżniającą jest ciągłe odwoływanie się i zaufanie do rozumu ludzkiego. Boecjusz, który sformułował zasadę postępowania naukowego, stosowaną i rozwijaną w całym średniowieczu, uczył, że w sprawach wiary badaj jak tylko możesz, jak dalece sięga

zowaną dziś wolność człowieka, tak komentuje te wydarzenia: „Niezależnie od interpretacji porażka rozumu podczas wydarzeń 1968 roku była oczywista dla każdego, kto widział je z bliska i kto zachował w sobie dostatecznie dużo pesymizmu [czytaj: realizmu — uwaga W.B.], aby potrafić rozpoznać ludzkie szaleństwo". Roger SCRUTON, Pożytki z pesymizmu i niebezpieczeństwa fatszywej nadziei, przeł. Tomasz Bieroń (Poznań: Zysk i S-ka, 2012), 59-61.

${ }^{11}$ Por. Wielgus, Z badań nad średniowieczem, 7-12.

${ }^{12}$ Pojęcie „scholastyka” (od łacińskiego słowa schola — szkoła) odnosi się do filozoficzno-teologicznej nauki rozwijanej i wykładanej w szkołach i uniwersytetach średniowiecznych, wedle określonej metody, z określonym merytorycznie programem. 
światełko ludzkiego rozumu, ratio dux - rozum przewodnikiem. Dwunastowieczny zaś autor Honoriusz z Autun pisał: „Wygnaniem człowieka jest ciemnota, jego ojczyzną jest wiedza” oraz: „Nie ma innego autorytetu jak prawda dowiedziona rozumem"13. Prawdą jest, że dla myślicieli średniowiecznych pierwszeństwo miała wiara, nigdy jednak sama, zawsze połączona $\mathrm{z}$ rozumem. Mówi o tym słynna zasada sformułowana w XI wieku przez Anzelma z Canterbury: Fides quaerens intellectum — „Wiara poszukująca zrozumienia", co oznacza, że w punkcie wyjścia należy z pokorą przyjąć to, co mówi wiara, ale dalej mamy obowiązek otrzymaną prawdę zrozumieć, wyjaśnić i uzasadnić. Nikt tak konsekwentnie i systemowo jak uczeni średniowieczni nie przywoływał i nie bronił ludzkiego rozumu. Rozum bowiem i związana z nim wolność są warunkami sine qua non chrześcijańskiej moralności; bez nich nie można mówić o odpowiedzialności za czyny, a co za tym idzie - o sądzie ostatecznym i sprawiedliwości. Bez rozumności i wolności człowieka traci sens całe chrześcijaństwo. Pewne potwierdzenie tych prawd znajdziemy w filozofii Immanuela Kanta, który idzie niejako dalej, twierdząc, że bez tych idei traci sens ludzkie życie, dlatego w moralności przyjął postulaty rozumu praktycznego: ludzką wolność, nieśmiertelność duszy ludzkiej, istnienie Boga, który jako gwarant sprawiedliwości rozliczy wszystkich na sądzie ostatecznym ${ }^{14}$.

Nawet Voltaire, chociaż był wrogiem chrześcijaństwa, uważał trzynastowieczny szczytowy okres scholastyki za jeden z nielicznych okresów w dziejach świata, które dowodzą wielkości ducha ludzkiego ${ }^{15}$. Ci jednak, którzy powtarzają dziś stereotyp o „ciemnym” średniowieczu, wykazują się kompletną niewiedzą na temat tej epoki. Pewien współczesny intelektualista tę ignorancję skwitował sarkastycznym stwierdzeniem: „Kto mówi, że średniowiecze było ciemne, dowodzi, że sam jest ciemny". Nasuwające się dziś analogie między schyłkowym okresem starożytności, przypadającym na czas rozpadu rzymskiego imperium, i współczesną epoką ponowoczesną, ogłoszoną jako epoka wyczerpania się twórczych możliwości europejskiej kultury, mogą rodzić pytanie, czy z tygla współczesnego zamętu cywilizacyjnego i wielkiego nieładu kulturowego, jak dawniej $\mathrm{z}$ wieków upadku, po wojnach i wędrówkach ludów, wyłoni się siła zdolna do stworzenia

\footnotetext{
${ }^{13}$ Jacques Le Goff, Inteligencja w wiekach średnich, przeł. Eligia Bąkowska (Warszawa: Oficyna Wydawnicza Volumen, Dom Wydawniczy Bellona, 1997), 80, 73.

${ }^{14}$ Zob. Frederick Copleston, Historia filozofii, t. 6: Od Wolffa do Kanta, przeł Jerzy Łoziński (Warszawa: Instytut Wydawniczy Pax, 2005), 292-298.

${ }^{15}$ Por. Christopher Dawson, Szkice o kulturze średniowiecznej, przeł. Jan Sulowski (Warszawa: Instytut Wydawniczy Pax, 1966), 152.
} 
nowej jakości kulturowej, sprzyjającej pełnemu rozwojowi człowieka we wszystkich jego wymiarach? Wracając do pytań postawionych na początku, czy współczesne społeczeństwo byłoby zdolne stwarzać nowe renesansy budowane m.in. ze „starych” średniowiecznych idei, odpowiedzi na powyższe pytania będziemy szukać w analizie internetowych badań ankietowych, przeprowadzonych na potrzeby niniejszego artykułu.

\section{METODOLOGIA BADAŃ}

Przedmiotem prezentowanych badań jest określenie stanu wiedzy na temat kultury średniowiecznej i współczesnego postrzegania tejże epoki. Celem badań jest analiza poznawcza opinii współczesnego społeczeństwa na temat mitu „ciemnego” średniowiecza, analiza porównawcza społecznych determinantów postrzegania epoki średniowiecza dzisiaj oraz ustalenie ich źródeł (społecznych, kulturowych, edukacyjnych i medialnych).

$\mathrm{Na}$ wstępie procesu badawczego przyjęto hipotezę, że w świadomości społecznej współczesnego człowieka funkcjonuje mit „ciemnego” średniowiecza. Uzupełnienie hipotezy głównej stanowią hipotezy szczegółowe:

1. Wiek respondentów nie różnicuje ich opinii na temat średniowiecza.

2. Opinie o epoce średniowiecza determinuje wykształcenie respondentów. Im wyższe wykształcenie respondentów, tym lepsza znajomość epoki, implikująca jego korzystniejsze oceny.

3. Głównym źródłem informacji o średniowieczu są podręczniki szkolne.

Internetowe badania ankietowe zostały przeprowadzone na przełomie października i listopada 2020 r. wśród 150 anonimowych respondentów, należących do różnych grup społecznych i wiekowych. Ankieta została zamieszczona na portalu internetowym https://docs.google.com. Dzięki przyjętej formie badania uzyskano wyniki w jak największym stopniu przekrojowe, nieograniczone terenowo, chociaż niereprezentatywne. 


\section{ILOŚCIOWA ANALIZA ZAWARTOŚCI}

Tabela 1. Wiek respondentów

\begin{tabular}{|l|l|c|c|}
\hline \multirow{2}{*}{ L.p. } & \multirow{2}{*}{ Wiek } & \multicolumn{2}{|c|}{ Liczba respondentów: 150} \\
\cline { 3 - 4 } & & Liczba & $\%$ \\
\hline 1. & poniżej 19 lat & 26 & 17,3 \\
\hline 2. & $19-25$ & 51 & 34,0 \\
\hline 3. & $25-40$ & 19 & 12,7 \\
\hline 4. & $40-60$ & 34 & 22,7 \\
\hline 5. & powyżej 60 lat & 20 & 13,3 \\
\hline Łącznie & & 150 & 100,0 \\
\hline
\end{tabular}

Źródło: opracowanie własne na podstawie badań ankietowych

Z uzyskanych danych wynika, że jedną trzecią badanych $(34,0 \%)$ stanowią osoby w przedziale wiekowym 19-25 lat. Na drugim miejscu uplasowali się respondenci w wieku od 40-60 lat $(22,7 \%)$. Dalej kolejno: osoby poniżej 19 lat $(17,3 \%)$ oraz powyżej 60 roku życia $(13,3 \%)$. Najmniejszą liczbę badanych $(12,7 \%)$ odnotowano w obszarze wiekowym od $25-40$ roku życia.

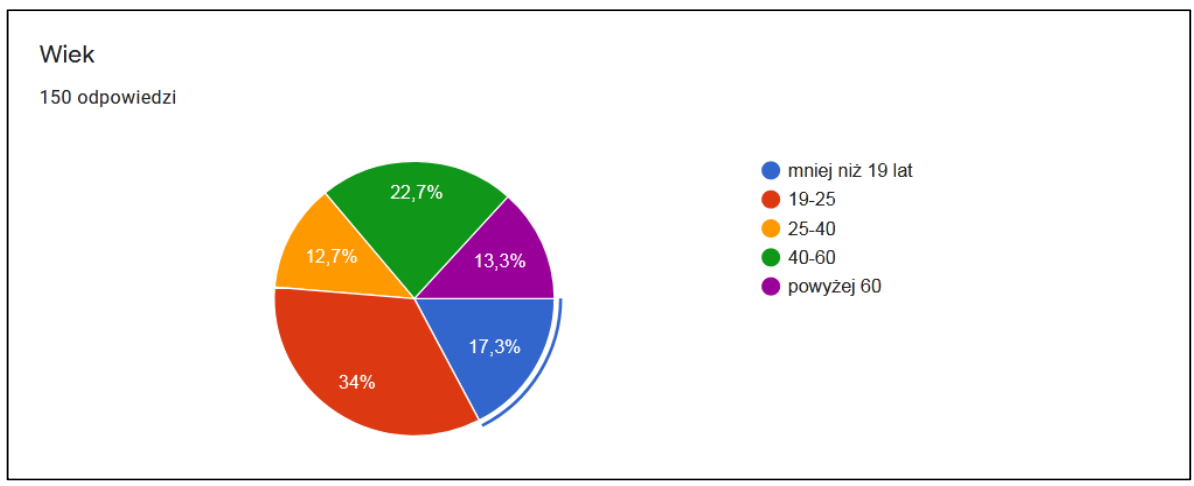

Źródło: opracowanie własne na podstawie badań ankietowych 


\begin{tabular}{|l|l|c|c|}
\hline Tabela 2. Wykształcenie respondentów & \multirow{2}{*}{ Wykształcenie } & \multicolumn{2}{|c|}{ Liczba respondentów: 150} \\
\cline { 3 - 4 } & & Liczba & $\%$ \\
\hline 1. & & 12 & 8,0 \\
\hline 2. & podstawowe & 11 & 7,3 \\
\hline 3. & gimnazjalne & 7 & 4,7 \\
\hline 4. & zasadnicze zawodowe & $56+1$ (Student) & $37,3+0,7$ \\
\hline 5. & średnie & 63 & 42,0 \\
\hline Łącznie & wyższe & 150 & 100,0 \\
\hline
\end{tabular}

Źródło: opracowanie własne na podstawie badań ankietowych

Ze zgromadzonych danych (tabela 2) wynika, że kwestionariusz ankiety najchętniej wypełniały osoby $\mathrm{z}$ wykształceniem wyższym (42\%) oraz średnim $(38 \%)$, w następnej kolejności ankietowani z wykształceniem podstawowym (8\%) i gimnazjalnym (7,3\%), najmniejszą grupę zaś stanowią osoby z wykształceniem zasadniczym zawodowym $(4,7 \%)$.

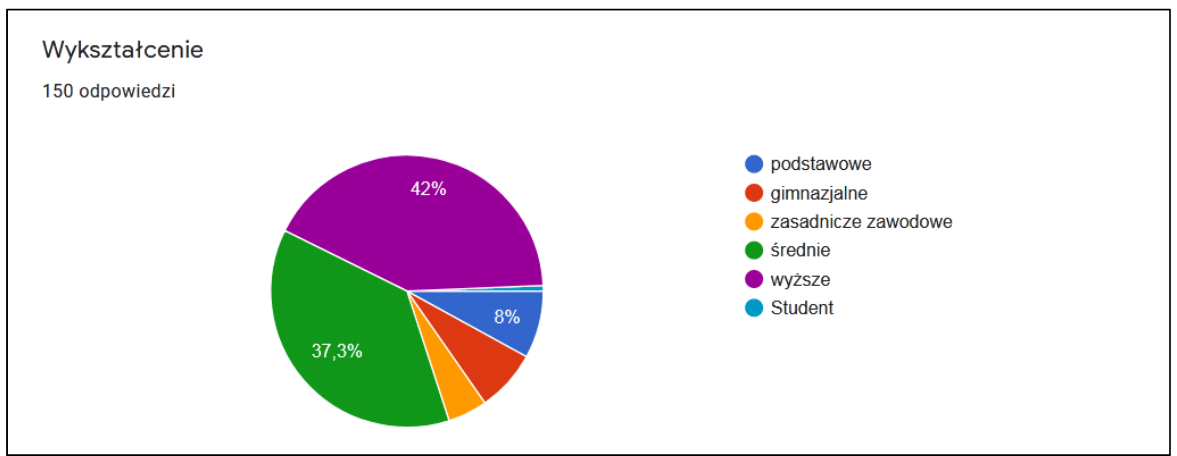

Źródło: opracowanie własne na podstawie badań ankietowych

Tabela 3. Miejsce zamieszkania

\begin{tabular}{|l|l|c|c|}
\hline \multirow{2}{*}{ L.p. } & \multirow{2}{*}{ Liczba mieszkańców } & \multicolumn{2}{|c|}{ Liczba odpowiedzi: 150} \\
\cline { 3 - 4 } & & Liczba & $\%$ \\
\hline 1. & do 2 tys. mieszkańców & 36 & 24,0 \\
\hline 2. & $2-20$ tys. (małe miasta) & 36 & 24,0 \\
\hline 3. & $20-100$ tys. (średnie miasta) & 38 & 25,3 \\
\hline 4. & 100 tys. i więcej (duże miasta) & 40 & 26,7 \\
\hline Łącznie & & 150 & 100,0 \\
\hline
\end{tabular}

Źródło: opracowanie własne na podstawie badań internetowych 
Jak wynika z tabeli 3, najwięcej ankietowanych pochodzi z dużych miast - powyżej 100 tys. mieszkańców (26,7\%). Porównywalne ilościowo są grupy badanych zamieszkujących średnie miasta $(25,3 \%)$ oraz małe miasta i miejscowości do 2 tysięcy mieszkańców (po 24,0\%).

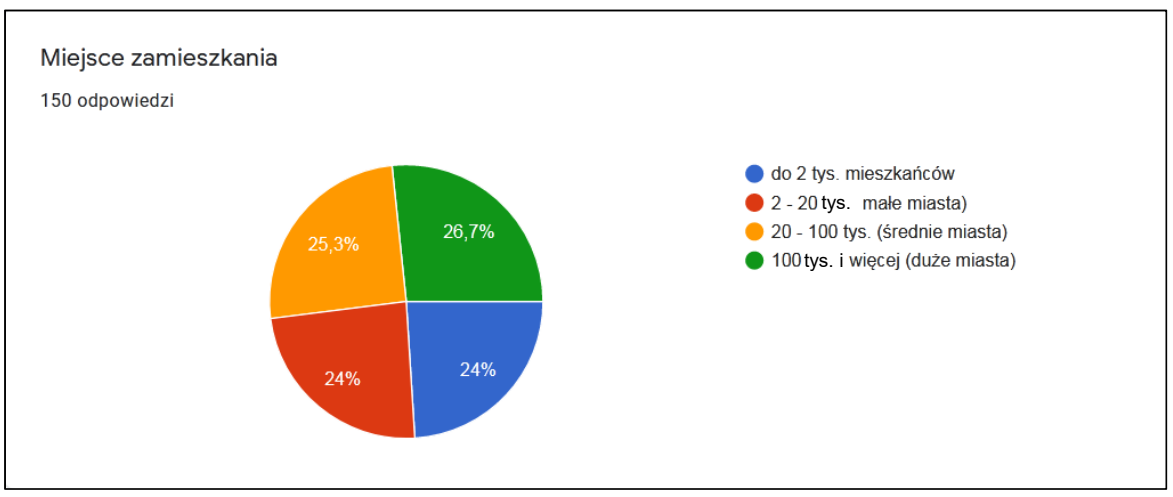

Źródło: opracowanie własne na podstawie badań ankietowych

\section{EKSPLORACJA WYNIKÓW}

Kwestionariusz ankiety zawierał trzy pytania zamknięte wielokrotnego wyboru $^{16}, \mathrm{z}$ możliwością podania własnej odpowiedzi, oraz jedno pytanie otwarte, umożliwiające przedstawienie respondentom osobistego zdania na temat epoki średniowiecza.

Pierwsze pytanie, na które odpowiedzi udzieliło 144 badanych, zawierało argumenty/przesłanki potwierdzające mit „ciemnego” średniowiecza (Pytanie: Średniowiecze byto „ciemne”, ponieważ ...).

\footnotetext{
${ }^{16}$ Ponieważ respondenci mieli możliwość wielokrotnego wyboru odpowiedzi, suma odpowiedzi przekracza $100 \%$.
} 


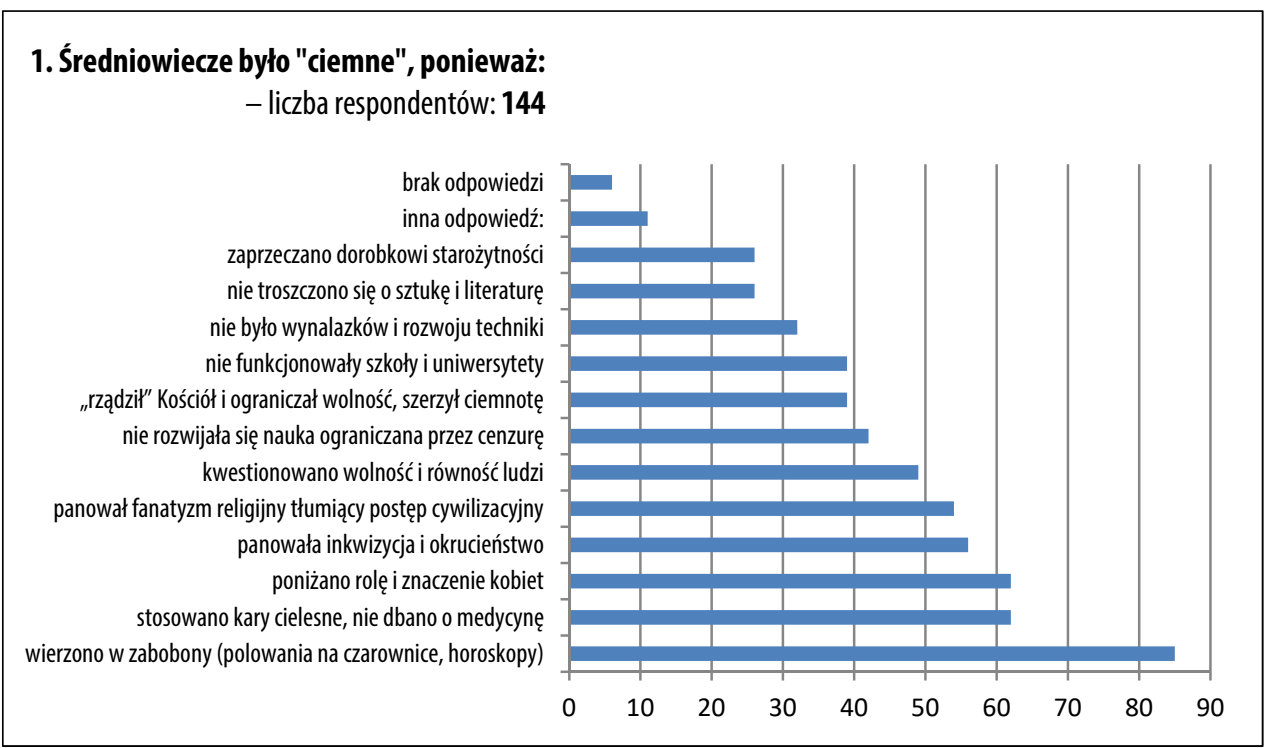

Źródło: opracowanie własne na podstawie badań ankietowych

Tabela 4. Argumenty/opinie potwierdzające mit „ciemnego" średniowiecza

\begin{tabular}{|c|c|c|c|}
\hline \multirow{2}{*}{ L.p. } & \multirow{2}{*}{ Średniowiecze było „ciemne”, ponieważ: } & \multicolumn{2}{|c|}{$\begin{array}{l}\text { Liczba respondentów: } \\
\qquad 144\end{array}$} \\
\hline & & Liczba & $\%$ \\
\hline 1. & wierzono w zabobony (polowania na czarownice, horoskopy) & 85 & 59,0 \\
\hline 2. & stosowano kary cielesne, nie dbano o medycynę & 62 & 43,1 \\
\hline 3. & poniżano rolę i znaczenie kobiet & 62 & 43,1 \\
\hline 4. & panowała inkwizycja i okrucieństwo & 56 & 38,9 \\
\hline 5. & panował fanatyzm religijny tłumiący postęp cywilizacyjny & 54 & 37,5 \\
\hline 6. & kwestionowano wolność i równość ludzi & 49 & 34,0 \\
\hline 7. & nie rozwijała się nauka ograniczana przez cenzurę & 42 & 29,2 \\
\hline 8. & „"zządził” Kościół i ograniczał wolność, szerzył ciemnotę & 39 & 27,1 \\
\hline 9. & nie funkcjonowały szkoły i uniwersytety & 39 & 27,1 \\
\hline 10. & nie było wynalazków i rozwoju techniki & 32 & 22,2 \\
\hline 11. & nie troszczono się o sztukę i literaturę & 26 & 18,1 \\
\hline 12. & zaprzeczano dorobkowi starożytności & 26 & 18,1 \\
\hline 13. & inna odpowiedź: & 11 & 7,7 \\
\hline
\end{tabular}




\begin{tabular}{|c|c|c|c|}
\hline & Bo fałszywy humanizm tak chce & 2 & 1,4 \\
\hline & Nie zgadzam się z powyższym stwierdzeniem & 1 & 0,7 \\
\hline & $\begin{array}{r}\text { Doszło do upadku Zachodniego Cesarstwa Rzymskiego w wyniku najazdów ludów } \\
\text { koczowniczych, które doprowadziło również do zastoju w spisywaniu kronik, datowaniu } \\
\text { wydarzeń i dokumentowaniu wydarzeń, jakie działy się w tamtym okresie historii, } \\
\text { zaś przybyłe ludy koczownicze nie potrafity przez lata skorzystać z dorobku starożytnych, } \\
\text { którego nie rozumieli. }\end{array}$ & 1 & 0,7 \\
\hline & Uważam, że absolutnie nie można stwierdzić, że średniowiecze było ciemne. & 1 & 0,7 \\
\hline & $\begin{array}{r}\text { Koncentrowało się tylko na sprawach religii, zaniedbując całościowy } \\
\text { rozwój człowieka. }\end{array}$ & 1 & 0,7 \\
\hline & Niski poziom higieny & 1 & 0,7 \\
\hline & Nie zgadzam się z żadną z tych tez. & 1 & 0,7 \\
\hline & Średniowiecze dało ludzkości uniwersytety, które zapoczątkowały rozwój nauki. & 1 & 0,7 \\
\hline & $\begin{array}{l}\text { To fałszywa opinia lansowana przez środowiska oświeceniowe, a potem marksistowsko- } \\
\text {-komunistyczne w celu dezawuowania roli Kościoła w okresie średniowiecza. }\end{array}$ & 1 & 0,7 \\
\hline & Nie było "ciemne". & 1 & 0,7 \\
\hline & Łącznie: liczba odpowiedzi & 583 & - \\
\hline 14. & Brak odpowiedzi & 6 & 4,2 \\
\hline
\end{tabular}

Źródło: opracowanie własne na podstawie badań internetowych

Odpowiedzi na analizowane pytanie udzieliło 144 respondentów spośród 150, którzy łącznie wyrazili 583 opinii (tabela 4). Większość badanych ( 85 osób; 59\%) uważa, że średniowiecze było „ciemne”, bo wierzono w zabobony (polowania na czarownice, horoskopy). Mniej niż połowa ankietowanych (62 osoby; 43,1\%) wymieniała stosowanie kar cielesnych, zaniedbywanie medycyny oraz poniżanie roli i znaczenia kobiet. Natomiast 56 respondentów wskazało na panowanie inkwizycji i okrucieństwa $(38,9 \%)$.

Opinie respondentów różnicuje ich wiek. Chociaż przedstawiciele wszystkich grup wiekowych wskazali na odpowiedz: wierzono $w$ zabobony (polowania na czarownice), to należy odnotować znaczne różnice procentowe. Osoby z przedziału wiekowego 25-40 lat dwa razy częściej wskazywały na tę odpowiedź w porównaniu do osób powyżej 60 roku życia (79\% wobec $35 \%)$. Jest to najwyżej punktowana odpowiedź w tym przedziale wiekowym. $\mathrm{Na}$ drugim miejscu, wskazało na nie po 62 ankietowanych, uplasowały się dwie odpowiedzi: stosowano kary cielesne, nie dbano o medycynę oraz poni- 
żano rolę i znaczenie kobiet. Była one najczęściej wybierana przez najmłodszych respondentów (> 19 lat: 50\% i 58\%), osoby w wieku studenckim (1925 lat: 49\% i 51\%) oraz z przedziału wiekowego 40-60 lat: 38\%. Kolejnym argumentem przemawiającym — w opinii respondentów — za „ciemnym” średniowieczem jest przekonanie o panowaniu inkwizycji i okrucieństwa w analizowanej epoce. Pogląd ten podziela ponad połowa badanych $(53 \%)$ w wieku 25-40 lat, prawie połowa (46\%) najmłodszych respondentów oraz $35 \%$ ankietowanych powyżej 60 roku życia.

Tabela 5. Wiek respondentów a argumenty/opinie potwierdzające mit „ciemnego" średniowiecza

\begin{tabular}{|c|c|c|c|c|c|c|c|c|c|c|c|c|}
\hline \multirow{3}{*}{ L.p. } & \multirow{3}{*}{ Średniowiecze było „ciemne”, ponieważ: } & \multicolumn{10}{|c|}{ Wiek respondentów ${ }^{17}$} & \multirow{3}{*}{$\frac{\text { łącznie }}{\mathrm{L}}$} \\
\hline & & \multicolumn{2}{|c|}{$>19$ lat } & \multicolumn{2}{|c|}{$19-25$} & \multicolumn{2}{|c|}{$25-40$} & \multicolumn{2}{|c|}{$40-60$} & \multicolumn{2}{|c|}{$<60$ lat } & \\
\hline & & L & $\%$ & $\mathrm{~L}$ & $\%$ & $\mathrm{~L}$ & $\%$ & L & $\%$ & L & $\%$ & \\
\hline 1. & $\begin{array}{l}\text { wierzono w zabobony (polowania na } \\
\text { czarownice) }\end{array}$ & 15 & 58 & 31 & 61 & 15 & 79 & 17 & 50 & 7 & 35 & 85 \\
\hline 2. & stosowano kary cielesne, nie dbano o medycynę & 13 & 50 & 25 & 49 & 7 & 37 & 13 & 38 & 4 & 20 & 62 \\
\hline 3. & poniżano rolę i znaczenie kobiet & 15 & 58 & 26 & 51 & 7 & 37 & 11 & 32 & 3 & 15 & 62 \\
\hline 4. & panowała inkwizycja i okrucieństwo & 12 & 46 & 19 & 37 & 10 & 53 & 8 & 24 & 7 & 35 & 56 \\
\hline 5. & $\begin{array}{l}\text { panował fanatyzm religijny tłumiący postęp } \\
\text { cywilizacyjny }\end{array}$ & 7 & 27 & 21 & 41 & 9 & 47 & 12 & 35 & 5 & 25 & 54 \\
\hline 6. & kwestionowano wolność i równość ludzi & 11 & 42 & 21 & 41 & 4 & 21 & 7 & 21 & 6 & 30 & 49 \\
\hline 7. & $\begin{array}{l}\text { nie rozwijała się nauka ograniczana przez } \\
\text { cenzurę }\end{array}$ & 9 & 35 & 17 & 33 & 7 & 37 & 8 & 24 & 1 & 5 & 42 \\
\hline 8. & $\begin{array}{l}\text { "rządził” Kościół i ograniczał wolność, szerzył } \\
\text { ciemnotę }\end{array}$ & 5 & 19 & 12 & 24 & 7 & 37 & 9 & 26 & 6 & 30 & 39 \\
\hline 9. & nie funkcjonowały szkoły i uniwersytety & 9 & 35 & 11 & 22 & 5 & 26 & 10 & 29 & 4 & 20 & 39 \\
\hline 10. & nie było wynalazków i rozwoju techniki & 4 & 15 & 6 & 12 & 7 & 37 & 7 & 21 & 8 & 40 & 32 \\
\hline 11. & nie troszczono się o sztukę i literaturę & 3 & 12 & 9 & 18 & 4 & 21 & 6 & 18 & 4 & 20 & 26 \\
\hline 12. & zaprzeczano dorobkowi starożytności & 4 & 15 & 11 & 22 & 3 & 16 & 4 & 12 & 4 & 20 & 26 \\
\hline \multirow[t]{2}{*}{13.} & inna odpowiedź: & - & - & 3 & - & - & - & 4 & - & 4 & - & 11 \\
\hline & Bo fałszywy humanizm tak chce & & & & & & & 2 & 6 & & & 2 \\
\hline
\end{tabular}

\footnotetext{
${ }^{17}$ Wskaźnik procentowy był wyliczany w stosunku do liczby respondentów tworzących dany przedział wiekowy
} 


\begin{tabular}{|c|c|c|c|c|c|c|c|c|c|c|c|c|}
\hline & Nie zgadzam się z powyższym . & & & & & & & 1 & 3 & & & 1 \\
\hline & Doszło do upadku Zachodniego Cesarstwa... & & & 1 & 2 & & & & & & & 1 \\
\hline & Uważam, że absolutnie nie można ... & & & 1 & 2 & & & & & & & 1 \\
\hline & Koncentrowało się tylko na sprawach ... & & & & & & & 1 & 3 & & & 1 \\
\hline & Niski poziom higieny & & & 1 & 2 & & & & & & & 1 \\
\hline & Nie zgadzam się z żadną z tych tez & & & & & & & & & 1 & 5 & 1 \\
\hline & Średniowiecze dało ludzkości ... & & & & & & & & & 1 & 5 & 1 \\
\hline & To fałszywa opinia lansowana przez ... & & & & & & & & & 1 & 5 & 1 \\
\hline & Nie było „ciemne” & & & & & & & & & 1 & 5 & 1 \\
\hline & Łącznie: liczba odpowiedzi & 107 & - & 212 & - & 85 & - & 116 & - & 63 & - & 583 \\
\hline 14. & Brak odpowiedzi & 2 & - & 1 & - & 3 & - & - & - & - & - & 6 \\
\hline 15. & $\begin{array}{l}\text { Średnia liczba argumentów przypadająca } \\
\text { na } 1 \text { osobę }\end{array}$ & 4,12 & - & 4,16 & - & 4,47 & - & 3,30 & - & 3,15 & - & 3,84 \\
\hline
\end{tabular}

Źródło: opracowanie własne na podstawie badań ankietowych

Kolorem żółtym zaznaczono trzy odpowiedzi o najwyższym wskaźniku procentowym w danej kategorii.

Legenda: $\mathrm{L}$ — Liczba respondentów, \% — Procent respondentów

Z tabeli 5 wynika też, że najwięcej argumentów potwierdzających mit „ciemnego” średniowiecza podali respondenci w wieku 25-40 lat (uśredniony wynik dla 1 osoby: 4,47), natomiast najmniej osoby powyżej 60 lat (uśredniony wynik dla 1 osoby: 3,15 ).

Kolejną zmienną determinującą opinie respondentów w zakresie postrzegania „ciemnego” średniowiecza jest ich wykształcenie. Należy zauważyć, że chociaż osoby $\mathrm{z}$ wszystkich analizowanych przedziałów wiekowych wskazały na odpowiedz, że: wierzono $w$ zabobony (polowania na czarownice), to kolejne możliwe odpowiedzi są bardziej zróżnicowane. Osoby o najniższym wykształceniu wymieniały kolejno panowanie inkwizycji i okrucieństwa $(58 \%)$ oraz poniżanie roli i znaczenia kobiet $(50 \%)$. Respondenci posiadający wykształcenie gimnazjalne obok wiary w zabobony w jednakowym stopniu wyliczały stosowanie kar cielesnych, nie dbanie o medycynę, poniżanie roli i znaczenia kobiet (po 55\%), następnie: kwestionowanie wolności i równości ludzi (45\%) oraz — po 36\% — panowała inkwizycja i okrucieństwo oraz nie rozwijała się nauka ograniczana przez cenzurę. Respondenci deklarujący wykształcenie zasadnicze zawodowe, obok odpowiedzi/ argumentów wskazanych przez większość badanych, zwrócili uwagę przede 
wszystkim na to, że nie było wynalazków i rozwoju techniki (86\%), nie troszczono się o sztukę i literaturę $(57 \%)$ oraz - po $43 \%$ - nie funkcjonowały szkoły i uniwersytety, zaprzeczano dorobkowi starożytności. Ankietowani z wykształceniem średnim (49\%) oraz wyższym (32\%) wskazali też, że panował fanatyzm religijny tłumiący postęp cywilizacyjny.

Tabela 6. Wykształcenie respondentów a argumenty/opinie potwierdzające mit "ciemnego" średniowiecza

\begin{tabular}{|c|c|c|c|c|c|c|c|c|c|c|c|c|}
\hline \multirow{3}{*}{ L.p. } & \multirow{3}{*}{$\begin{array}{l}\text { Średniowiecze było „ciemne”, } \\
\text { ponieważ: }\end{array}$} & \multicolumn{10}{|c|}{ Wykształcenie respondentów } & \multirow{3}{*}{$\begin{array}{c}\text { łącznie } \\
\mathrm{L}\end{array}$} \\
\hline & & \multicolumn{2}{|c|}{ podstawowe } & \multicolumn{2}{|c|}{ gimnazjalne } & \multicolumn{2}{|c|}{$\begin{array}{l}\text { zasadnicze } \\
\text { zawodowe }\end{array}$} & \multicolumn{2}{|c|}{ średnie } & \multicolumn{2}{|c|}{ wyższe } & \\
\hline & & $\mathrm{L}$ & $\%$ & L & $\%$ & $\mathrm{~L}$ & $\%$ & $\mathrm{~L}$ & $\%$ & $\mathrm{~L}$ & $\%$ & \\
\hline 1. & $\begin{array}{l}\text { wierzono w zabobony (polowania na } \\
\text { czarownice) }\end{array}$ & 8 & 67 & 6 & 55 & 4 & 57 & 30 & 53 & 37 & 59 & 85 \\
\hline 2. & $\begin{array}{l}\text { stosowano kary cielesne, nie dbano } 0 \\
\text { medycynę }\end{array}$ & 5 & 42 & 6 & 55 & 3 & 43 & 26 & 46 & 22 & 35 & 62 \\
\hline 3. & poniżano rolę i znaczenie kobiet & 6 & 50 & 6 & 55 & 3 & 43 & 31 & 54 & 16 & 25 & 62 \\
\hline 4. & panowała inkwizycja i okrucieństwo & 7 & 58 & 4 & 36 & 4 & 57 & 24 & 42 & 17 & 27 & 56 \\
\hline 5. & $\begin{array}{l}\text { panował fanatyzm religijny tłumiący } \\
\text { postęp cywilizacyjny }\end{array}$ & 5 & 42 & 0 & 0 & 1 & 14 & 28 & 49 & 20 & 32 & 54 \\
\hline 6. & $\begin{array}{l}\text { kwestionowano wolność i równość } \\
\text { ludzi }\end{array}$ & 3 & 25 & 5 & 45 & 2 & 29 & 20 & 35 & 19 & 30 & 49 \\
\hline 7. & $\begin{array}{l}\text { nie rozwijała się nauka ograniczana } \\
\text { przez cenzurę }\end{array}$ & 3 & 25 & 4 & 36 & 2 & 29 & 19 & 33 & 14 & 22 & 42 \\
\hline 8. & $\begin{array}{l}\text { „rządził” Kościół i ograniczał wolność, } \\
\text { szerzył ciemnotę }\end{array}$ & 3 & 25 & 1 & 9 & 2 & 29 & 18 & 32 & 15 & 24 & 39 \\
\hline 9. & $\begin{array}{l}\text { nie funkcjonowały szkoły i } \\
\text { uniwersytety }\end{array}$ & 5 & 42 & 3 & 27 & 3 & 43 & 15 & 26 & 13 & 21 & 39 \\
\hline 10. & $\begin{array}{l}\text { nie było wynalazków i rozwoju } \\
\text { techniki }\end{array}$ & 2 & 17 & 4 & 36 & 6 & 86 & 7 & 12 & 12 & 21 & 32 \\
\hline 11. & nie troszczono się o sztukęi literaturę & 1 & 8 & 2 & 18 & 4 & 57 & 11 & 19 & 8 & 13 & 26 \\
\hline 12. & zaprzeczano dorobkowi starożytności & 1 & 8 & 1 & 9 & 3 & 43 & 10 & 18 & 11 & 17 & 26 \\
\hline \multirow[t]{4}{*}{13.} & inna odpowiedź: & - & - & - & - & - & - & 2 & 4 & 9 & 17 & 11 \\
\hline & Bo fałszywy humanizm... & & & & & & & & & 2 & 3 & 2 \\
\hline & Nie zgadzam się... & & & & & & & & & 1 & 2 & 1 \\
\hline & Doszło do upadku Zachodniego... & & & & & & & 1 & 2 & & & 1 \\
\hline
\end{tabular}




\begin{tabular}{|r|r|r|r|r|r|r|r|r|r|r|r|c|}
\hline & Uważam, że absolutnie... & & & & & & & 1 & $\mathbf{2}$ & & & $\mathbf{1}$ \\
\hline & Koncentrowało sie tylko... & & & & & & & & & 1 & $\mathbf{2}$ & $\mathbf{1}$ \\
\hline Niski poziom higieny & & & & & & & & & 1 & $\mathbf{2}$ & $\mathbf{1}$ \\
\hline Nie zgadzam się... & & & & & & & & & 1 & $\mathbf{2}$ & $\mathbf{1}$ \\
\hline & Średniowiecze dało ludzkósi... & & & & & & & & & 1 & $\mathbf{2}$ & $\mathbf{1}$ \\
\hline & To fałszywa opinia... & & & & & & & & & 1 & $\mathbf{2}$ & $\mathbf{1}$ \\
\hline 14. & Brak odpowiedzi było „ciemne" & & & & & & & & & 1 & $\mathbf{2}$ & $\mathbf{1}$ \\
\hline 15. & $\begin{array}{l}\text { Średnia liczba argumentów } \\
\text { przypadająca na 1 osobę }\end{array}$ & 4,08 & - & 3,81 & - & 5,28 & - & 0,42 & - & 3,36 & - & $\mathbf{3 , 3 9}$ \\
\hline
\end{tabular}

Źródło: opracowanie własne na podstawie badań ankietowych

Kolorem żółtym zaznaczono trzy odpowiedzi o najwyższym wskaźniku procentowym w danej kategorii.

Legenda: L — Liczba respondentów, \% — Procent respondentów

Z uzyskanych danych wynika, że najwięcej argumentów potwierdzających negatywne opinie na temat analizowanej epoki zaznaczyli respondenci z wykształceniem zasadniczym zawodowym - uśredniony wynik dla 1 osoby wynosi: 5,28 , natomiast najmniej osoby $\mathrm{z}$ wykształceniem średnim - co drugi badany: 0,42 .

Miejsce zamieszkania respondentów minimalnie różnicuje ich opinie. Co najmniej połowa ankietowanych reprezentujących wszystkie analizowane grupy wskazała na odpowiedź: wierzono $w$ zabobony (polowania na czarownice). Ponad jedna trzecia badanych wymieniła stosowanie kar cielesnych, zaniedbywanie medycyny. Natomiast argument za poniżaniem roli kobiet uzyskał bardziej zróżnicowane oceny. Najrzadziej wymieniali go ankietowani pochodzący z miejscowości do 2 tysięcy mieszkańców (31\%), natomiast najczęściej mieszkańcy średnich miast (55\%: 20-100 tys.). Stąd różnica procentowa wynosi 24 punkty procentowe (p.p.). Respondenci są najbardziej zgodni w zakresie oceny inkwizycji i okrucieństwa: 36\%: $>2$ tys.; 36\%: 2-20 tys.; 39\%: 20-100 tyś.; 38\%: < 100 tys. mieszkańców. 
Tabela 7. Miejsce zamieszkania respondentów a argumenty/opinie potwierdzające mit "ciemnego" średniowiecza

\begin{tabular}{|c|c|c|c|c|c|c|c|c|c|c|}
\hline \multirow{3}{*}{ L.p. } & \multirow{3}{*}{$\begin{array}{l}\text { Miejsce zamieszkania a opinie za „ciemnym” } \\
\text { średniowieczem }\end{array}$} & \multicolumn{9}{|c|}{ Liczba mieszkańców } \\
\hline & & \multicolumn{2}{|c|}{$>2$ tys. } & \multicolumn{2}{|c|}{$2-20$ tys. } & \multicolumn{2}{|c|}{$20-100$ tys. } & \multicolumn{2}{|c|}{$<100$ tys. } & \multirow{2}{*}{$\frac{\text { Łącznie }}{\mathbf{L}}$} \\
\hline & & L & $\%$ & $\mathrm{~L}$ & $\%$ & L & $\%$ & $\mathrm{~L}$ & $\%$ & \\
\hline 1. & wierzono w zabobony (polowania na czarownice) & 21 & 58 & 22 & 61 & 22 & 58 & 20 & 50 & 85 \\
\hline 2. & stosowano kary cielesne, nie dbano o medycynę & 12 & 33 & 17 & 47 & 17 & 45 & 16 & 40 & 62 \\
\hline 3. & poniżano rolę i znaczenie kobiet & 11 & 31 & 13 & 36 & 21 & 55 & 17 & 43 & 62 \\
\hline 4. & panowała inkwizycja i okrucieństwo & 13 & 36 & 13 & 36 & 15 & 39 & 15 & 38 & 56 \\
\hline 5. & $\begin{array}{l}\text { panował fanatyzm religijny tłumiący postęp } \\
\text { cywilizacyjny }\end{array}$ & 13 & 36 & 11 & 31 & 13 & 34 & 17 & 43 & 54 \\
\hline 6. & kwestionowano wolność i równość ludzi & 10 & 28 & 9 & 25 & 15 & 39 & 15 & 38 & 49 \\
\hline 7. & nie rozwijała się nauka ograniczana przez cenzurę & 8 & 22 & 10 & 28 & 15 & 39 & 9 & 23 & 42 \\
\hline 8. & „rządził” Kościół i ograniczał wolność, szerzył ciemnotę & 9 & 25 & 8 & 22 & 9 & 24 & 13 & 33 & 39 \\
\hline 9. & nie funkcjonowały szkoły i uniwersytety & 8 & 22 & 13 & 36 & 10 & 26 & 8 & 20 & 39 \\
\hline 10. & nie było wynalazków i rozwoju techniki & 8 & 22 & 10 & 28 & 8 & 21 & 6 & 15 & 32 \\
\hline 11. & nie troszczono się o sztukę i literaturę & 6 & 17 & 6 & 17 & 9 & 24 & 5 & 13 & 26 \\
\hline 12. & zaprzeczano dorobkowi starożytności & 7 & 19 & 7 & 19 & 6 & 16 & 6 & 15 & 26 \\
\hline \multirow[t]{12}{*}{13.} & inna odpowiedź: & 3 & 9 & 2 & 6 & - & - & 6 & 18 & 11 \\
\hline & Bo fałszywy humanizm... & & & 2 & 6 & & & & & 2 \\
\hline & Nie zgadzam się... & & & & & & & 1 & 3 & 1 \\
\hline & Doszło do upadku Zachodniego... & 1 & 3 & & & & & & & 1 \\
\hline & Uważam, że absolutnie... & 1 & 3 & & & & & & & 1 \\
\hline & Koncentrowało sie tylko... & & & & & & & 1 & 3 & 1 \\
\hline & Niski poziom higieny & 1 & 3 & & & & & & & 1 \\
\hline & Nie zgadzam się... & & & & & & & 1 & 3 & 1 \\
\hline & Średniowiecze dało ludzkości... & & & & & & & 1 & 3 & 1 \\
\hline & To fałszywa opinia... & & & & & & & 1 & 3 & 1 \\
\hline & Nie było „ciemne”. & & & & & & & 1 & 3 & 1 \\
\hline & Łącznie: liczba odpowiedzi & 129 & - & 141 & - & 160 & - & 153 & - & 583 \\
\hline 14. & Brak odpowiedzi & 4 & - & - & - & 2 & - & - & - & 6 \\
\hline
\end{tabular}

Źródło: opracowanie własne na podstawie badań ankietowych Kolorem żółtym zaznaczono trzy odpowiedzi o najwyższym wskaźniku procentowym w danej kategorii. Legenda: L — Liczba respondentów. \% — Procent respondentów 
Jednym z celów badawczych było ustalenie źródeł informacji o epoce średniowiecza. Na pytanie: Skąd mam tę wiedze o średniowieczu odpowiedzi udzieliło 143 respondentów, w tym 14 podało inne, własne źródła. Badani mieli możliwość zaznaczenia kilku odpowiedzi.

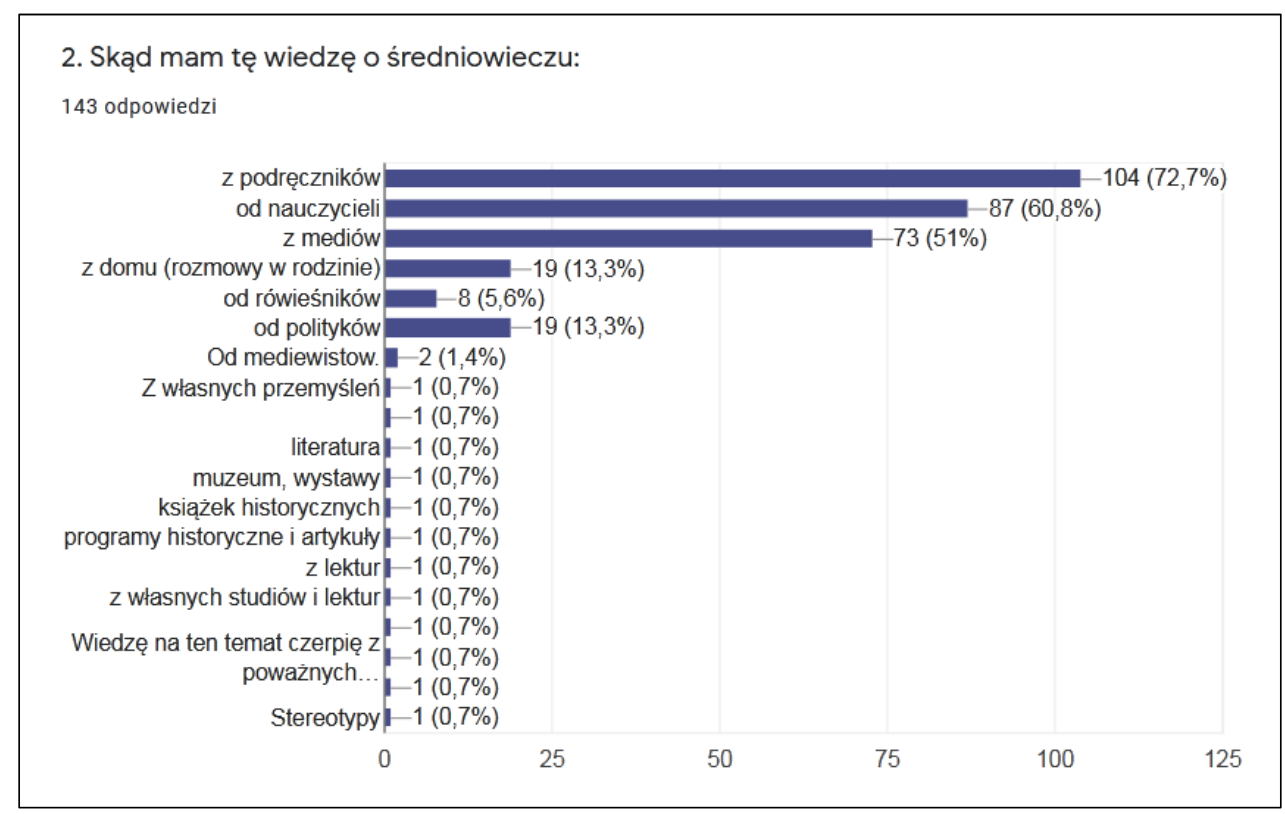

Źródło: opracowanie własne na podstawie badań ankietowych

Zdecydowana większość respondentów — 104 na 143 osoby (tabela 8) wiedzę o epoce średniowiecza posiada z podręczników (72,7\%). Ankietowani często wskazywali także na nauczycieli $(60,8 \%)$ oraz środki masowego przekazu $(51,0 \%)$. Co piąty badany jako źródło podał przekazy formułowane przez polityków - osoby publiczne, członków rodziny - osoby prywatne. Sporadycznie - najczęściej najmłodsi uczestnicy badań — wskazywali na rówieśników. Natomiast osoby powyżej 60 roku życia najchętniej podawali własne źródła informacji o epoce średniowiecza. 
Tabela 8. Źródła wiedzy o epoce średniowiecza

\begin{tabular}{|c|c|c|c|}
\hline \multirow{2}{*}{ L.p. } & \multirow{2}{*}{ Skąd mam tę wiedzę o średniowieczu? } & \multicolumn{2}{|c|}{ Liczba odpowiedzi: 143} \\
\hline & & Liczba & $\%$ \\
\hline 1. & z podręczników & 104 & 72,7 \\
\hline 2. & od nauczycieli & 87 & 60,8 \\
\hline 3. & z mediów & 73 & 51,0 \\
\hline 4. & od polityków & 19 & 13,3 \\
\hline 5. & z domu (rozmowy w rodzinie) & 19 & 13,3 \\
\hline 6. & od rówieśników & 8 & 5,6 \\
\hline 7. & inne: & 14 & 9,8 \\
\hline & od mediewistów & 2 & 1,4 \\
\hline & z własnych przemyśleń & 1 & 0,7 \\
\hline & z lektur & 1 & 0,7 \\
\hline & muzeum, wystawy & 1 & 0,7 \\
\hline & $\begin{array}{r}\text { artykuły o średniowieczu, filmy na YouTube, } \\
\text { z książek i atlasów historycznych }\end{array}$ & 1 & 0.7 \\
\hline & literatura & 1 & 0,7 \\
\hline & programy historyczne i artykuły & 1 & 0,7 \\
\hline & książek historycznych & 2 & 1,4 \\
\hline & z własnych studiów i lektur & 1 & 0,7 \\
\hline & $\begin{array}{l}\text { W czasie studiów miałam lekturę obowiązkową: „Jesień } \\
\text { średniowiecza” Huizingi, ostatnio zagłębiłam się w dwie } \\
\text { książki Georga R. R. Martina: „Życie w średniowiecznym } \\
\text { mieście” i „Życie w średniowiecznym zamku”. }\end{array}$ & 1 & 0,7 \\
\hline & $\begin{array}{r}\text { Wiedzę na ten temat czerpię z poważnych opracowań } \\
\text { naukowych. }\end{array}$ & 1 & 0,7 \\
\hline & stereotypy & 1 & 0,7 \\
\hline & & 324 & \\
\hline 8. & Brak odpowiedzi & 7 & 4,9 \\
\hline
\end{tabular}

Źródło: opracowanie własne na podstawie badań ankietowych

Kolorem żółtym zaznaczono trzy odpowiedzi o najwyższym wskaźniku procentowym w danej kategorii.

Jednym z celów badawczych było określenie stanu wiedzy na temat kultury średniowiecznej i współczesne postrzeganie epoki średniowiecza. $\mathrm{Na}$ 
całościowy obraz epoki, obok argumentów ukazujących jej słabe strony, bezdyskusyjnie składa się jej dorobek, osiągnięcia, wynalazki czy poziom rozwoju nauki, kultury czy medycyny. Stąd kolejne - trzecie - pytanie miało na celu zweryfikowanie stanu wiedzy o argumentach potwierdzających wyjątkowość epoki, a tym samym obalających mit „ciemnego” średniowiecza. Formuła pytania umożliwiała respondentom wybór dowolnej liczby odpowiedzi wraz z możliwością podania własnej. Łącznie zostało wyrażonych 667 opinii. Pięciu na 150 ankietowanych nie udzieliło odpowiedzi na przedstawione w badaniu pytanie.

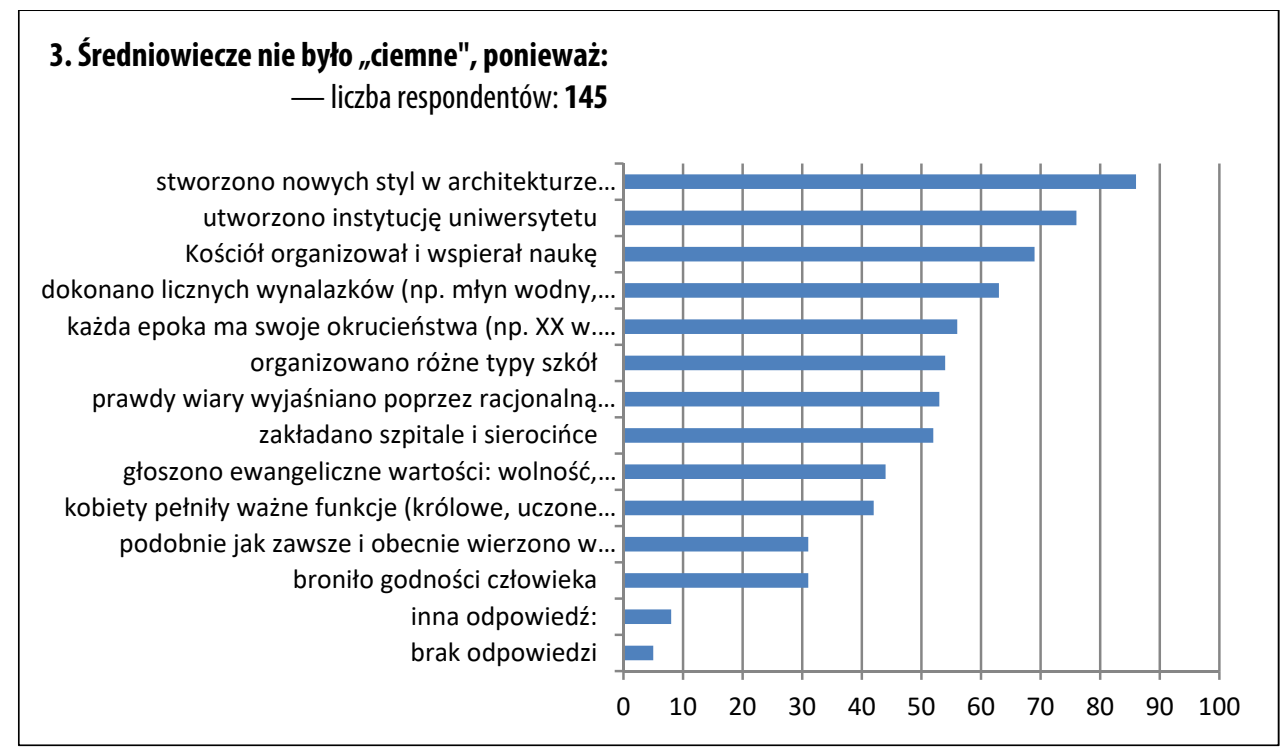

Źródło: opracowanie własne na podstawie badań ankietowych

Analizując zgromadzone dane (tabela 9), nasuwa się wniosek, że wielkość średniowiecza jest pochodną jego osiągnięć w kulturze, sztuce i nauce. Większość osób (86 na 145; 59,3\%), które wzięły udział w badaniach, uważa, że średniowiecze nie było „ciemne”, bo został wypracowany nowy styl w architekturze, malarstwie oraz muzyce. Należy zauważyć, że ten wskaźnik jest porównywalny z liczbą osób deklarujących odmienne zdanie (85 na 144; 59,0\% uważa, że średniowiecze było „ciemne”, bo wierzono w zabobony). Epokowość średniowiecza podkreślano w działaniach podejmowanych przez Kościół na rzecz rozwoju, organizacji i wspierania nauki (69; 47,6\%) i szkół $(54 ; 37,3 \%)$, a przede wszystkim utworzeniu instytucji uniwersytetu $(76 ; 52,4 \%)$, czego wymiernym efektem były liczne wynalazki 
(63; 43,4\%). Kolejne grupy stanowią argumenty o podłożu humanistycznym (każda epoka ma swoje okrucieństwa: np. XX w. holokaust, obozy koncentracyjne: 56; 38,6\%; broniło godności człowieka: 31; 21,4\%), teologicznym (prawdy wiary wyjaśniano poprzez racjonalna argumentację: 53; 36,6\%; głoszono ewangeliczne wartości: wolność, równość i braterstwo: 44; 30,3\%) oraz społecznym (zaktadano szpitale i sierocince: 52; 35,9\%; kobiety petnity ważne funkcje: $42 ; 29,0 \%)$.

Tabela 9. Argumenty/opinie obalające mit "ciemnego" średniowiecza

\begin{tabular}{|c|c|c|c|}
\hline \multirow{2}{*}{ L.p. } & \multirow{2}{*}{ Średniowiecze nie było „ciemne”, ponieważ: } & \multicolumn{2}{|c|}{ Liczba respondentów: 145} \\
\hline & & Liczba & $\%$ \\
\hline 1. & stworzono nowy styl w architekturze (malarstwie, muzyce) & 86 & 59,3 \\
\hline 2. & utworzono instytucję uniwersytetu & 76 & 52,4 \\
\hline 3. & Kościół organizował i wspierał naukę & 69 & 47,6 \\
\hline 4. & dokonano licznych wynalazków (np. młyn wodny, podkowa, produkcja papieru, weksel) & 63 & 43,4 \\
\hline 5. & każda epoka ma swoje okrucieństwa (np. XX w. holokaust, obozy koncentracyjne) & 56 & 38,6 \\
\hline 6. & organizowano różne typy szkół & 54 & 37,3 \\
\hline 7. & prawdy wiary wyjaśniano poprzez racjonalną argumentację & 53 & 36,6 \\
\hline 8. & zakładano szpitale i sierocińce & 52 & 35,9 \\
\hline 9. & głoszono ewangeliczne wartości: wolność, równość i braterstwo & 44 & 30,3 \\
\hline 10. & kobiety pełniły ważne funkcje (królowe, uczone mniszki) & 42 & 29,0 \\
\hline 11. & podobnie jak zawsze i obecnie wierzono w zabobony (np. horoskopy) & 31 & 21,4 \\
\hline 12. & broniło godności człowieka & 31 & 21,4 \\
\hline \multirow[t]{6}{*}{13.} & inna odpowiedź: & 8 & 5,6 \\
\hline & duchowni pisywali kroniki & 1 & 0,7 \\
\hline & $\begin{array}{r}\text { Kościół dążył do przywrócenia ładu, jaki panował przed upadkiem Zachodniego Cesarstwa } \\
\text { Rzymskiego, a przez ewangelię głosił wartości, które pomagały ludziom w chwilach } \\
\text { pełnych przeciwności. }\end{array}$ & 1 & 0,7 \\
\hline & Uważam, że było "ciemne" & 1 & 0,7 \\
\hline & Ciemne & 1 & 0,7 \\
\hline & Żadna z powyższych & 1 & 0,7 \\
\hline
\end{tabular}




\begin{tabular}{|c|c|c|c|}
\hline & $\begin{array}{l}\text { Owszem, kobiety pełniły ważne role, organizowano różne typy szkół, utworzono instytucje } \\
\text { uniwersytetu..., ale należy podkreślić, że były to działania skierowane tylko } \\
\text { do uprzywilejowanych osób, małej grupy. Te przywileje i możliwości wynikały z urodzenia. }\end{array}$ & 1 & 0,7 \\
\hline & Jednak „było ciemne” & 1 & 0,7 \\
\hline & $\begin{array}{r}\text { Przede wszystkim skłaniano ludzi do poszukiwania „rzeczy większych” i budzono } \\
\text { pasję tworzenia. Nie było wówczas ideologii, nawet jeśli popełniano błędy, } \\
\text { to nie podnoszono ich do „rangi sztuki”. }\end{array}$ & 1 & 0,7 \\
\hline & Łącznie: liczba odpowiedzi & 667 & - \\
\hline 14. & Brak odpowiedzi & 5 & 3,0 \\
\hline
\end{tabular}

Źródło: opracowanie własne na podstawie badań ankietowych

Argumenty badanych osób determinuje wiek respondentów. Chociaż reprezentanci wszystkich grup wiekowych wymieniali odpowiedź: stworzono nowy styl $w$ architekturze (malarstwie, muzyce), która uzyskała najwyższy wskaźnik procentowy, to zauważa się istotne różnice procentowe. Badani w wieku 19-25 lat dwa razy częściej wymieniali tę odpowiedź w porównaniu z nieco starszymi osobami (25-40 lat) (73\% wobec 37\%). Była to najczęściej wybierana odpowiedź przez osoby w wieku studenckim.

$\mathrm{Na}$ drugim miejscu, z uśrednionym wynikiem 76, uplasowała się odpowiedź odwołująca się do faktu utworzenia instytucji uniwersytetu. Chociaż zauważa się porównywalny wskaźnik procentowy we wszystkich grupach wiekowych (od $47 \%$ do $55 \%$ ), to obok powodów teologicznych (po 55\%: Kościól organizowat $i$ wspierat nauke oraz gloszono ewangeliczne wartości: wolność, równość $i$ braterstwo) jest to jeden z najważniejszych argumentów dla osób powyżej 60 roku życia. Mniej niż połowa respondentów $(47,6 \%)$ doceniła rolę Kościoła w organizowaniu i wspieraniu nauki. Różnica procentowa w poszczególnych grupach wiekowych oscyluje wokół 16 punktów procentowych. Warto dodać, że ta odpowiedź należy do najwyżej punktowanych wśród osób powyżej 60 lat, jednocześnie nie znalazła się wśród trzech najczęściej wybieranych przez młodzież studencką. 
Tabela 10. Wiek respondentów a argumenty /opinie obalające mit "ciemnego" średniowiecza

\begin{tabular}{|c|c|c|c|c|c|c|c|c|c|c|c|c|}
\hline \multirow{3}{*}{ L.p. } & \multirow{3}{*}{$\begin{array}{l}\text { Średniowiecze nie było } \\
\text { "ciemne", ponieważ: }\end{array}$} & \multicolumn{10}{|c|}{ Wiek respondentów } & \multirow{3}{*}{$\frac{\text { Łącznie }}{\mathrm{L}}$} \\
\hline & & \multicolumn{2}{|c|}{$>19$ lat } & \multicolumn{2}{|c|}{$19-25$} & \multicolumn{2}{|c|}{$25-40$} & \multicolumn{2}{|c|}{$40-60$} & \multicolumn{2}{|c|}{$<60$ lat } & \\
\hline & & L & $\%$ & L & $\%$ & L & $\%$ & $\mathrm{~L}$ & $\%$ & L & $\%$ & \\
\hline 1. & $\begin{array}{l}\text { stworzono nowy styl w architekt- } \\
\text { urze (malarstwie, muzyce) }\end{array}$ & 14 & 54 & 37 & 73 & 7 & 37 & 19 & 56 & 9 & 45 & 86 \\
\hline 2. & utworzono instytucję uniwersytetu & 13 & 50 & 26 & 51 & 9 & 47 & 17 & 50 & 11 & 55 & 76 \\
\hline 3. & Kościół organizował i wspierał naukę & 11 & 42 & 20 & 39 & 9 & 47 & 18 & 53 & 11 & 55 & 69 \\
\hline 4. & $\begin{array}{l}\text { dokonano licznych wynalazków } \\
\text { (np. młyn wodny, podkowa, } \\
\text { produkcja papieru, weksel) }\end{array}$ & 9 & 35 & 27 & 53 & 6 & 32 & 11 & 32 & 10 & 50 & 63 \\
\hline 5. & $\begin{array}{l}\text { każda epoka ma swoje } \\
\text { okrucieństwa (np. XX w. holokaust, } \\
\text { obozy koncentracyjne) }\end{array}$ & 8 & 26 & 24 & 47 & 6 & 32 & 11 & 32 & 7 & 35 & 56 \\
\hline 6. & organizowano różne typy szkół & 6 & 23 & 19 & 37 & 5 & 26 & 18 & 53 & 8 & 40 & 56 \\
\hline 7. & $\begin{array}{l}\text { prawdy wiary wyjaśniano poprzez } \\
\text { racjonalną argumentację }\end{array}$ & 8 & 31 & 14 & 27 & 7 & 37 & 14 & 41 & 10 & 50 & 53 \\
\hline 8. & zakładano szpitale i sierocińce & 8 & 31 & 16 & 31 & 5 & 26 & 15 & 44 & 8 & 40 & 52 \\
\hline 9. & $\begin{array}{l}\text { głoszono ewangeliczne wartości: } \\
\text { wolność, równość i braterstwo }\end{array}$ & 8 & 31 & 11 & 22 & 4 & 21 & 10 & 29 & 11 & 55 & 44 \\
\hline 10. & $\begin{array}{l}\text { kobiety pełniły ważne funkcje } \\
\text { (królowe, uczone mniszki) }\end{array}$ & 3 & 12 & 9 & 18 & 7 & 37 & 14 & 41 & 9 & 45 & 42 \\
\hline 11. & $\begin{array}{l}\text { podobnie jak zawsze i obecnie wie- } \\
\text { rzono w zabobony (np. horoskopy) }\end{array}$ & 2 & 8 & 7 & 14 & 3 & 16 & 11 & 32 & 8 & 40 & 31 \\
\hline 12. & broniło godności człowieka & 3 & 12 & 5 & 10 & 2 & 11 & 12 & 35 & 9 & 45 & 31 \\
\hline 13. & inna odpowiedź: & 2 & 8 & 1 & 2 & - & - & 4 & 12 & 1 & 5 & 8 \\
\hline & Duchowni pisywali kroniki & & & & & & & 1 & 3 & & & 1 \\
\hline & $\begin{array}{r}\text { Kościół dążył do przywrócenia ładu, } \\
\text { jaki panował przed upadkiem } \\
\text { Zachodniego Cesarstwa Rzym- } \\
\text { skiego, a przez ewangelię głosił } \\
\text { wartości, które pomagały ludziom } \\
\text { w chwilach pełnych przeciwności. }\end{array}$ & & & 1 & 2 & & & & & & & 1 \\
\hline
\end{tabular}




\begin{tabular}{|c|c|c|c|c|c|c|c|c|c|c|c|c|}
\hline & Uważam, że było "ciemne" & & & & & & & 1 & 3 & & & 1 \\
\hline & Ciemne & 1 & 4 & & & & & & & & & 1 \\
\hline & Żadna z powyższych & & & & & & & & & 1 & 5 & 1 \\
\hline & $\begin{array}{r}\text { Owszem, kobiety pełniły ważne } \\
\text { role, organizowano różne typy } \\
\text { szkół, utworzono instytucje } \\
\text { uniwersytetu..., ale należy } \\
\text { podkrésić, że były to działania } \\
\text { skierowane tylko do } \\
\text { uprzywilejowanych osób, } \\
\text { małej grupy. Te przywileje } \\
\text { i możliwości wynikały z urodzenia. }\end{array}$ & & & & & & & 1 & 3 & & & 1 \\
\hline & Jednak "było ciemne" & 1 & 4 & & & & & & & & & 1 \\
\hline & $\begin{array}{r}\text { Przede wszystkim skłaniano ludzi } \\
\text { do poszzukiwania „rzeczy } \\
\text { większych” i budzono pasję } \\
\text { tworzenia. Nie było wówczas } \\
\text { ideologii, nawet jeśli popełniano } \\
\text { błędy, to nie podnoszono ich } \\
\text { do „rangi sztuki”. }\end{array}$ & & & & & & & 1 & 3 & & & 1 \\
\hline & Łącznie: liczba odpowiedzi & 95 & - & 216 & - & 70 & - & 174 & - & 112 & - & 667 \\
\hline 14. & Brak odpowiedzi & 1 & - & 1 & - & 1 & - & 2 & - & - & - & 5 \\
\hline 15. & $\begin{array}{l}\text { Średnia liczba argumentów } \\
\text { przypadająca na } 1 \text { osobę }\end{array}$ & 3,65 & - & 4,23 & - & 3,68 & - & 5,11 & - & 5,6 & - & 4,45 \\
\hline
\end{tabular}

Źródło: opracowanie własne na podstawie badań ankietowych

Kolorem żółtym zaznaczono trzy odpowiedzi o najwyższym wskaźniku procentowym w danej kategorii.

Legenda: $\mathrm{L}$ — Liczba respondentów, \% — Procent respondentów

Wiek respondentów znacznie różnicuje liczbę przytaczanych argumentów obalających mit „ciemnego” średniowiecza. Średni wynik na jedną osobę oscyluje wokół 4,45 opinii. Najwięcej powodów podali badani powyżej 60 roku życia $(5,6)$, natomiast najmniej najmłodsi uczestnicy badań — osoby poniżej 19 lat: 3,65.

Obok wieku respondentów zmienną znacznie różnicującą opinie badanych jest ich wykształcenie. Badani z wykształceniem podstawowym zwrócili uwagę na argumenty współtworzące naukę (utworzono instytucję uniwersytetu: 50\%), kulturę (stworzono nowy styl w architekturze: malarstwie, 
muzyce: 42\%) i rozwój (dokonano licznych wynalazków (np. mlyn wodny, podkowa, produkcja papieru, weksel: 33\%) średniowiecza. Osoby, które ukończyły tylko gimnazjum, obok czynników kulturowych w jednakowym stopniu podkreślili rolę Kościoła w organizowaniu nauki oraz wskazali na aspekty humanistyczne (każda epoka ma swoje okrucieństwa (np. XX w. holokaust, obozy koncentracyjne) (po 45\%). Opinie respondentów deklarujących kwalifikacje zawodowe są bardzo rozproszone. Zwrócili oni uwagę na zdecydowaną większość możliwych przyczyn. Natomiast opinie osób z wykształceniem średnim i wyższym są bardzo spolaryzowane. Koncentrują się na rozwoju sztuki, kultury, nauki, utworzeniu instytucji uniwersytetu oraz organizowaniu różnego typy szkół.

Tabela 11. Wykształcenie respondentów a argumenty/opinie obalające mit "ciemnego" średniowiecza

\begin{tabular}{|c|c|c|c|c|c|c|c|c|c|c|c|c|}
\hline \multirow{3}{*}{ L.p. } & \multirow{3}{*}{$\begin{array}{l}\text { Średniowiecze nie było } \\
\text { „ciemne”, ponieważ: }\end{array}$} & \multicolumn{10}{|c|}{ Wykształcenie respondentów } & \multirow{3}{*}{$\frac{\text { łącznie }}{\text { L }}$} \\
\hline & & \multicolumn{2}{|c|}{ podstawowe } & \multicolumn{2}{|c|}{ gimnazjalne } & \multicolumn{2}{|c|}{$\begin{array}{l}\text { zasadnicze } \\
\text { zawodowe }\end{array}$} & \multicolumn{2}{|c|}{ średnie } & \multicolumn{2}{|c|}{ wyższe } & \\
\hline & & L & $\%$ & $\mathrm{~L}$ & $\%$ & $\mathrm{~L}$ & $\%$ & $\mathrm{~L}$ & $\%$ & $\mathrm{~L}$ & $\%$ & \\
\hline 1. & $\begin{array}{l}\text { stworzono nowych styl w architek- } \\
\text { turze (malarstwie, muzyce) }\end{array}$ & 5 & 42 & 5 & 45 & 2 & 29 & 36 & 63 & 38 & 60 & 86 \\
\hline 2. & utworzono instytucję uniwersytetu & 6 & 50 & 4 & 36 & 3 & 43 & 25 & 44 & 38 & 60 & 76 \\
\hline 3. & Kościół organizował i wspierał naukę & 3 & 25 & 5 & 45 & 3 & 43 & 22 & 39 & 36 & 57 & 69 \\
\hline 4. & $\begin{array}{l}\text { dokonano licznych wynalazków } \\
\text { (np. młyn wodny, podkowa, pro- } \\
\text { dukcja papieru, weksel) }\end{array}$ & 4 & 33 & 2 & 18 & 1 & 14 & 22 & 39 & 34 & 54 & 63 \\
\hline 5. & $\begin{array}{l}\text { każda epoka ma swoje okrucień- } \\
\text { stwa (np. XX w. holokaust, obozy } \\
\text { koncentracyjne) }\end{array}$ & 2 & 17 & 5 & 45 & 2 & 29 & 22 & 39 & 25 & 40 & 56 \\
\hline 6. & organizowano różne typy szkół & 2 & 17 & 2 & 18 & 0 & 0 & 18 & 32 & 34 & 54 & 56 \\
\hline 7. & $\begin{array}{l}\text { prawdy wiary wyjaśniano poprzez } \\
\text { racjonalną argumentację }\end{array}$ & 2 & 17 & 4 & 36 & 1 & 14 & 16 & 28 & 30 & 48 & 53 \\
\hline 8. & zakładano szpitale i sierocińce & 2 & 17 & 4 & 36 & 0 & 0 & 15 & 26 & 31 & 49 & 52 \\
\hline 9. & $\begin{array}{l}\text { głoszono ewangeliczne wartości: } \\
\text { wolność, równość i braterstwo }\end{array}$ & 3 & 25 & 4 & 36 & 2 & 29 & 13 & 23 & 22 & 35 & 44 \\
\hline 10. & $\begin{array}{l}\text { kobiety pełniły ważne funkcje } \\
\text { (królowe, uczone mniszki) }\end{array}$ & 2 & 17 & 1 & 9 & 3 & 43 & 12 & 21 & 24 & 38 & 42 \\
\hline
\end{tabular}




\begin{tabular}{|c|c|c|c|c|c|c|c|c|c|c|c|c|}
\hline 11. & $\begin{array}{l}\text { podobnie jak zawsze i obecnie wie- } \\
\text { rzono w zabobony (np. horoskopy) }\end{array}$ & 1 & 8 & 2 & 18 & 1 & 14 & 11 & 19 & 16 & 25 & 31 \\
\hline 12. & broniło godności człowieka & 1 & 8 & 3 & 27 & 2 & 29 & 5 & 9 & 20 & 32 & 31 \\
\hline \multirow[t]{10}{*}{13.} & inna odpowiedź: & 2 & 16 & 1 & 8 & - & - & 1 & 2 & 4 & 8 & 8 \\
\hline & duchowni pisywali kroniki & & & & & & & & & 1 & 2 & 1 \\
\hline & Kościół dążył do przywrócenia ładu ... & & & & & & & 1 & 2 & & & 1 \\
\hline & Uważam, że było „ciemne” & & & & & & & & & 1 & 2 & 1 \\
\hline & Ciemne & & & 1 & 8 & & & & & & & 1 \\
\hline & Żadna z powyższych & 1 & 8 & & & & & & & & & 1 \\
\hline & Owszem, kobiety pehniły ważne role ... & & & & & & & & & 1 & 2 & 1 \\
\hline & Jednak „było ciemne” & 1 & 8 & & & & & & & & & 1 \\
\hline & $\begin{array}{r}\text { Przede wszystkim skłaniano ludzi } \\
\text { do poszukiwania ... }\end{array}$ & & & & & & & & & 1 & 2 & 1 \\
\hline & Łącznie: liczba odpowiedzi & 35 & - & 42 & - & 20 & - & 218 & - & 352 & - & 667 \\
\hline 14. & Brak odpowiedzi & 2 & - & 1 & - & - & - & 2 & - & - & - & 5 \\
\hline 15. & $\begin{array}{l}\text { Średnia liczba argumentów } \\
\text { przypadająca na } 1 \text { osobę }\end{array}$ & 2,91 & - & 3,81 & - & 2,85 & - & 3,82 & - & 5,58 & - & 3,79 \\
\hline
\end{tabular}

Źródło: opracowanie własne na podstawie badań ankietowych

Kolorem żółtym zaznaczono trzy odpowiedzi o najwyższym wskaźniku procentowym w danej kategorii.

Legenda: L — Liczba respondentów, \% — Procent respondentów

Ze zgromadzonych danych wynika, że najwięcej argumentów obalających mit „ciemnego" średniowiecza podali respondenci posiadający wykształcenie wyższe; uśredniony wynik dla 1 osoby wynosi 5,58. Natomiast najmniej: osoby z wykształceniem zasadniczym zawodowym i podstawowym; średnio mniej niż trzy argumenty $(2,85$ i 2,91$)$. Porównywalny jest wynik dla osób z wykształceniem średnim i gimnazjalnym $(3,82$ i 3,81$)$; mniej niż cztery argumenty.

Dokonując analizy zależności miejsca zamieszkania respondentów i opinii obalających mit „ciemnego” średniowiecza, zauważa się, że badani najbardziej są zgodni w kwestii utworzenia nowego stylu w architekturze, malarstwie i muzyce. Różnica procentowa oscyluje wokół 10 punktów procentowych (od 53\% — osoby zamieszkujące małe miejscowości - do 63\% mieszkańcy wielkich miast). Kolejno badani podobnie ocenili utworzenie instytucji uniwersytetu (różnica 11 p.p.) oraz poziom wiary w zabobony 
i horoskopy (różnica 12 p.p.). Miejsce zamieszkania najbardziej różnicuje opinie respondentów w kwestii zakładania szpitali i sierocińców (różnica 28 p.p.); od $22 \%$ - badani z miejscowości do 2 tys. mieszkańców — do $50 \%$ - respondenci z miast powyżej 100 tys. mieszkańców.

Tabela 12. Miejsce zamieszkania respondentów a argumenty/opinie obalające mit "ciemnego" średniowiecza

\begin{tabular}{|c|c|c|c|c|c|c|c|c|c|c|}
\hline \multirow{3}{*}{ L.p. } & \multirow{3}{*}{ Średniowiecze nie było „ciemne” ponieważ: } & \multicolumn{8}{|c|}{ Liczba mieszkańców } & \multirow{3}{*}{$\frac{\text { łącznie }}{\mathbf{L}}$} \\
\hline & & \multicolumn{2}{|c|}{$>2$ tys. } & \multicolumn{2}{|c|}{$2-20$ tys. } & \multicolumn{2}{|c|}{$20-100$ tys. } & \multicolumn{2}{|c|}{$<100$ tys. } & \\
\hline & & $\mathrm{L}$ & $\%$ & L & $\%$ & L & $\%$ & $\mathrm{~L}$ & $\%$ & \\
\hline 1. & $\begin{array}{l}\text { stworzono nowy styl w architekturze } \\
\text { (malarstwie, muzyce) }\end{array}$ & 19 & 53 & 20 & 56 & 22 & 58 & 25 & 63 & 86 \\
\hline 2. & utworzono instytucję uniwersytetu & 17 & 47 & 15 & 42 & 19 & 50 & 25 & 63 & 76 \\
\hline 3. & Kościół organizował i wspierał naukę & 17 & 47 & 20 & 56 & 13 & 34 & 19 & 48 & 69 \\
\hline 4. & $\begin{array}{l}\text { dokonano licznych wynalazków (np. młyn wod- } \\
\text { ny, podkowa, produkcja papieru, weksel) }\end{array}$ & 10 & 28 & 18 & 50 & 15 & 39 & 20 & 50 & 63 \\
\hline 5. & $\begin{array}{l}\text { każda epoka ma swoje okrucieństwa (np. XX w. } \\
\text { holokaust, obozy koncentracyjne) }\end{array}$ & 9 & 25 & 12 & 33 & 16 & 42 & 19 & 48 & 56 \\
\hline 6. & organizowano różne typy szkół & 10 & 28 & 12 & 33 & 14 & 37 & 20 & 50 & 56 \\
\hline 7. & $\begin{array}{l}\text { prawdy wiary wyjaśniano poprzez racjonalną } \\
\text { argumentację }\end{array}$ & 11 & 31 & 14 & 39 & 9 & 24 & 19 & 48 & 53 \\
\hline 8. & zakładano szpitale i sierocińce & 8 & 22 & 11 & 31 & 13 & 34 & 20 & 50 & 52 \\
\hline 9. & $\begin{array}{l}\text { głoszono ewangeliczne wartości: wolność, } \\
\text { równość i braterstwo }\end{array}$ & 9 & 25 & 14 & 39 & 6 & 16 & 15 & 38 & 44 \\
\hline 10. & $\begin{array}{l}\text { kobiety pełniły ważne funkcje (królowe, uczone } \\
\text { mniszki) }\end{array}$ & 7 & 19 & 10 & 28 & 8 & 21 & 17 & 43 & 42 \\
\hline 11. & $\begin{array}{l}\text { podobnie jak zawsze i obecnie wierzono w } \\
\text { zabobony (np. horoskopy) }\end{array}$ & 7 & 19 & 7 & 19 & 6 & 16 & 11 & 28 & 31 \\
\hline 12. & broniło godności człowieka & 3 & 8 & 12 & 33 & 4 & 11 & 12 & 30 & 31 \\
\hline \multirow[t]{4}{*}{13.} & inna odpowiedź: & 2 & 6 & - & - & 2 & 6 & 4 & 12 & 8 \\
\hline & duchowni pisywali kroniki & & & & & & & 1 & 3 & 1 \\
\hline & Kościół dążył do przywrócenia ładu ... & 1 & 3 & & & & & & & 1 \\
\hline & Uważam, że było „ciemne” & & & & & & & 1 & 3 & 1 \\
\hline
\end{tabular}




\begin{tabular}{|r|r|r|r|r|r|r|r|r|c|c|}
\hline Ciemne & & & & & & & 1 & $\mathbf{3}$ & 1 \\
\hline & Żadna z powyżzzych & 1 & $\mathbf{3}$ & & & & & & & 1 \\
\hline & 0wszem, kobiety pełniły ważne role ... & & & & & & & 1 & $\mathbf{3}$ & 1 \\
\hline Jednak „było ciemne" & & & & & 1 & $\mathbf{3}$ & & & 1 \\
\hline & $\begin{array}{r}\text { Przede wszystkim skłaniano ludzi do } \\
\text { poszukiwania ... }\end{array}$ & & & & & 1 & $\mathbf{3}$ & & & 1 \\
\hline 14. & Brak odpowiedzi & $\mathbf{1 2 9}$ & - & $\mathbf{1 6 5}$ & - & $\mathbf{1 4 7}$ & - & $\mathbf{2 2 6}$ & - & $\mathbf{6 6 7}$ \\
\hline
\end{tabular}

Źródło: opracowanie własne na podstawie badań ankietowych

Kolorem żółtym zaznaczono trzy odpowiedzi o najwyższym wskaźniku procentowym w danej kategorii.

Legenda: $\mathrm{L}$ — Liczba respondentów, \% — Procent respondentów

\section{JAKOŚCIOWA ANALIZA TREŚCI}

Ostatnie - czwarte - pytanie miało charakter otwarty. Mimo że umożliwiało uczestnikom badań przedstawienie osobistego zdania na temat średniowiecza, to tylko mniej niż połowa badanych skorzystała $\mathrm{z}$ tej możliwości. Łącznie udzielili oni 71 odpowiedzi, w tym jedną „pustą” (odpowiedź 50), która w dalszej analizie została potraktowana jako „brak odpowiedzi”.

Tabela 13. Wiek respondentów a indywidualne opinie/wypowiedzi na temat średniowiecza

\begin{tabular}{|l|l|c|c|}
\hline \multirow{2}{*}{ L.p. } & \multirow{2}{*}{ Wiek } & \multicolumn{2}{|c|}{ Liczba respondentów: 70 } \\
\cline { 3 - 4 } & & Liczba & $\%$ \\
\hline 1. & Mniej niż 19 lat & 8 odpowiedzi na 28 & 28,6 \\
\hline 2. & $19-25$ & 25 odpowiedzi na 51 & 49,0 \\
\hline 3. & $25-40$ & 11 odpowiedzi na 19 & 57,8 \\
\hline 4. & $40-60$ & 15 odpowiedzi na 34 & 44,1 \\
\hline 5. & powyżej 60 lat & 11 odpowiedzi na 20 & 55,0 \\
\hline & tącznie: liczba odpowiedzi & $\mathbf{7 0}$ & 46,7 \\
\hline 6. & Brak odpowiedzi & 80 & 53,3 \\
\hline
\end{tabular}

Źródło: opracowanie własne na podstawie badań ankietowych

Kolorem żółtym zaznaczono trzy odpowiedzi o najwyższym wskaźniku procentowym w danej kategorii. 
Spośród respondentów, którzy zdecydowali się na wyrażenie własnego zdania na temat średniowiecza (tabela 13), najbardziej aktywne były osoby w przedziale wiekowym 25-40 lat (57,8\%), a dalej kolejno osoby powyżej 60 roku życia $(55,0 \%)$ oraz w wieku studenckim, czyli 19-25 lat $(49,0 \%)$. Należy odnotować znaczne dysproporcje w częstotliwości wyrażania własnej opinii. Zauważa się, że najmłodsza grupa wiekowa (mniej niż 19 lat) dwa razy rzadziej dzieliła się swoimi ocenami w porównaniu do grupy wiekowej o najwyższym wskaźniku procentowym (28,6\% wobec 57,8\%). Poniżej przedstawiono wypowiedzi respondentów $\mathrm{z}$ uwzględnieniem kryterium wiekowego.

\section{OSOBY PONIŻEJ 19 LAT -8 ODPOWIEDZI NA 28 (28,6\%)}

- „Moim zdaniem stwierdzenie «ciemne średniowiecze» jest często używane jako, w pewnym sensie, technika manipulacyjna. Ma to pokazywać zacofanie Kościoła lub partii politycznych, które swoje programy opierają na nauce Kościoła. Średniowiecze jest teraz uważane za epokę ludzi «głupich». Dobitniej ma to pokazać określenie: «ciemne». Jako katolik uważam, że prawdy wiary nie były tak bardzo przestrzegane (np. palenie «wiedźm» na stosie), ale jeśli chodzi o liczebność chrześcijan, to dzisiejszy świat pozostawia jeszcze dużo do życzenia. I właśnie pod aspektem duchowym (który jest dla mnie najważniejszy) uważam, że to dzisiejszy świat jest zacofany względem średniowiecza" (Odpowiedź 14, podstawowe, $2-20$ tys. - małe miasto $)^{18}$.

- „Nie dbano o higienę osobistą, choroby” (Odpowiedź 139, średnie, do 2 tys. mieszkańców).

- „Rozwój filozoficzny był na bardzo wysokim poziomie (Tomasz z Akwinu, św. Augustyn), choć technologicznie stal nisko" (Odpowiedź 120, gimnazjalne, 100 tyś. i więcej: duże miasto).

- „Średniowiecze było ciekawą epoką, niestety wiele ludzi widzi je jako ciemny okres, pomijając wiele odkryć i wynalazków, które w niej powstały" (Odpowiedź 87, podstawowe, 2-20 tys. - małe miasto).

- „Średniowiecze jak każda inna epoka wniosła dobre i zle rzeczy, poglądy, rozwiązania dla ludzkości” (Odpowiedź 11, średnie, do 2 tys. mieszkańców).

\footnotetext{
${ }^{18}$ Numer wypełnionej ankiety na stronie internetowej, wykształcenie, miejsce zamieszkania respondenta.
} 
- „W każdym micie są elementy prawdy. Więc i w tych odnoszących się do średniowiecza" (Odpowiedź 73, gimnazjalne, 100 tys. i więcej — duże miasto).

- „Z tego, co ja wiem, to ważnymi wartościami były: Bóg, honor i ojczyzna, co bardzo doceniam i mi się podoba. Dodatkowo było dużo rycerzy, którzy dzielnie walczyli, bronili etosu i swoich ukochanych" (Odpowiedź 126, gimnazjalne, 100 tys. i więcej — duże miasto).

- „Ze względu na fanatyzm religijny odrzucono większość odkryć starożytnych, uznając ich za pogan, co przyczyniło się do znacznego spadku poziomu wiedzy. Dodatkowo Kościół utrudniał dostęp do wiedzy, ponieważ dawała ona władzę. Prawdy teologiczne opierano na poglądach ojców Kościoła, nie myślano nad nimi samodzielnie. Nowe teorie naukowe byly często uznawane za herezje. Nie oznacza to jednak, że nie powstawały szkoły i uczelnie. Nauka w nich polegała głównie na powtarzaniu, zgodnie $\mathrm{z}$ hasłem repetito est mater studiorum. Było wiele wolnych dni świątecznych. Przez niewielki stan wiedzy mas wciąż popularne były zabobony, $w$ tym te dotyczące medycyny. Wiele chorób uznawano za wynik działania sil nieczystych. Mimo to w średniowieczu dokonano wielu wynalazków, głównie tych ułatwiających pracę lub czyniących ją wydajniejszą. Mimo całego dorobku średniowiecza nie da się zaprzeczyć, że było ono epoką ciemną" (Odpowiedź 129, średnie, 100 tys. i więcej — duże miasto).

\section{OSOBY W WIEKU 19-25 LAT — 25 ODPOWIEDZI NA $51(49,0 \%)$}

- „Epoka bogata w wydarzenia kulturalne i historyczne, ale deprecjonowana przez powszechnie panującą opinię" (Odpowiedź 65, średnie, do 2 tys. mieszkańców).

- „Epoka Średniowiecza z pewnością nie byla ciemniejsza od czasów teraźniejszych, wręcz ludzie dzisiejsi mogą czerpać ogromne wzorce z pomysłowości, zaradności ludzi wieków średnich" (Odpowiedź 110, średnie, 2-20 tys. - małe miasto).

- „Jest interesujące” (Odpowiedź 48, średnie, 20-100 tys. - średnie miasto).

- „Każda epoka sprzeciwia się epoce, która jest przed nią — średniowiecze sprzeciwilo się epoce starożytnej. Powstały nowe style $w$ architekturze i malarstwie - zgoła odmienne od starożytnych. W średniowieczu bardzo ważną rolę pelnił Kościól katolicki, gdyż w tym czasie tylko 
państwa chrześcijańskie liczyły się na arenie międzynarodowej, władza duchowna była ważna na dworach królewskich, sieć parafialna umożliwiała głoszenie Ewangelii na ogromnym terenie, co wiązało się też z pewnymi wpływami materialnymi do centralnych władz kościelnych (tzn. biskupstwa stawały się coraz bogatsze, podczas gdy proste parafie-wierni i księża tam pracujący często „klepali biedę”), ponadto Kościół był mecenasem sztuki, osoby duchowne były wykształcone i umożliwiało to spisywanie dokumentów, czy dziejów danego państwa czy też władcy. Czy były to wieki ciemne? $\mathrm{Z}$ jednej strony — tak, tj. niewyksztalceni, prości ludzie nie mieli pełnej wolności (nie mogli opuszczać swoich wiosek, nie mieli własności, odrabiali pańszczyznę czasem nawet 6 dni w tygodniu, a 7 dnia pracować nie mogli ze względu na Dzień Pański, itd.), nie mieli wiedzy o świecie przez co byli łatwowierni, wierzyli w zabobony, dawali się „zastraszać”, tj. czuli przymus np. kupowania relikwii, bo bali się, że nie zostaną zbawieni i trafią do piekła. Ale $z$ drugiej strony - w średniowieczu powstało wiele narzędzi/technik, które przyczyniły się do rozwoju techniki, powstal druk - wynalazek ogromnie ważny, powstawały uniwersytety, rozwijała się nauka (choć z pewnymi ograniczeniami - mam na myśli Księgi Zakazane), sztuka. Na pewno w porównaniu do starożytności średniowiecze nie jawi się jako światła epoka, ale moim zdaniem całkowite deprecjonowanie średniowiecza nie jest do końca sprawiedliwe, gdyż była to po prostu kolejna epoka w historii świata ze swoimi blaskami i cieniami” (Odpowiedź 132, wyższe, do 2 tys. mieszkańców).

- „Lubię uczyć się o średniowieczu, jednak to, co tam się działo, jest dość straszne. Szczególnie te wszystkie inkwizycje i herezje. I blokowanie nauki" (Odpowiedź 27, średnie, 100 tys. i więcej - duże miasto).

- „Mógłbym w nim trochę pożyć, ale tylko jako król” (Odpowiedź 92, średnie, do 2 tys. mieszkańców).

- „Nie była rozwijana edukacja” (Odpowiedź 40, średnie, 20-100 tys. średnie miasto).

- „Średniowiecze było czasem rozwoju szkolnictwa, nauki i wynalazków" (Odpowiedź 12, średnie, do 2 tys. mieszkańców).

- „Średniowiecze było dość intensywną, pod względem wydarzeń, epoką historyczną, w której kościół licznymi działaniami, często z różnymi skutkami, staral się przywrócić lad moralny, kulturowy oraz cywilizacyjny, a także nie dopuścić do zapanowania całkowitej anarchii 
oraz degradacji dorobku cywilizacyjnego i kulturowego, zaś wszelkie negatywne wydarzenia $z$ historii średniowiecza są wynikiem niewłaściwych ludzi, którzy różnymi środkami doszli do władzy i w swoich działaniach wykorzystywali najbardziej delikatne oraz najbardziej wyczulone rejony czlowieczeństwa do wywierania na nich wpływu (lęki i niepokoje ludzi, pragnienie autorytetu, uznawanie pewnych wartości za kluczowe w życiu człowieka)" (Odpowiedź 41, średnie, do 2 tys. mieszkańców).

- „Średniowiecze było epoką przejściową, a więc pewne rzeczy musiały się w niej wydarzyć. Czy było to dobre, czy bylo to zle - musiało mieć miejsce, by wpłynąć na mentalność" (Odpowiedź 144, wyższe, 20-100 tys. - średnie miasto).

- „Średniowiecze było okresem, w którym duże znaczenie miał honor i obowiązki wobec swojego pana. Zaniedbana została medycyna, nie skupiano się na rozwoju intelektualnym (wyjątkiem mogą być mnisi), a na sile i zdobyczach" (Odpowiedź 28, średnie, 100 tys. i więcej duże miasto).

- „Średniowiecze kojarzy mi się z lekkim zacofaniem kulturowym. Wierzono $w$ czarownice $i$ magię, dużą rolę $w$ życiu odgrywała religia, teocentryzm, sztuka podporządkowana była religii. Nauka byla odrzucana (Mikołaj Kopernik i jego dzieło O obrotach sfer niebieskich)" (Odpowiedź 146, średnie, 20-100 tys. — średnie miasto).

- „Średniowiecze kojarzy mi się z wszechobecną religią, ascetami kreatywnością (mam na myśli ciekawe metody leczenia). Oprócz tego najwięcej jednak pamiętam z dziel sztuki, np. Dzieje Tristana i Izoldy, Pieśń o Rolandzie czy Kwiatki świętego Franciszka" (Odpowiedź 37, średnie, 100 tys. i więcej - duże miasto).

- „Średniowiecze mi się kojarzy z zacofaniem cywilizacji, fanatyzmem religijnym, zabobonami i różnorodnym okrutnym sprzętem do inkwizycji” (Odpowiedź 56, wyższe, 100 tys. i więcej — duże miasto).

- „Średniowiecze nie było do końca złe ani do końca dobre. Tak naprawdę gdyby ograniczyć rolę Kościoła i być bardziej wyrozumialym dla kobiet i heretyków byłby to dobry czas dla wielu uczonych, gdzie bez obaw mogliby szerzyć swoje poglądy. Był to także dobry czas dla rozwoju nauki i sztuki" (Odpowiedź 25, średnie, 2-20 tys. - małe miasto).

- „Średniowiecze to epoka jak każda inna, charakteryzowala się powrotem do antyku, historia już tak ma, że lubi się powtarzać. Uważam, że 
błędnie jest nazywana "wiekami ciemnymi»" (Odpowiedź 63, średnie, 100 tys. i więcej — duże miasto).

- „Średniowiecze, tak jak każda epoka, miało swoje wady i zalety. $\mathrm{Na}$ pewno negatywnymi cechami byly cenzura i wiara $w$ zabobony. $Z$ drugiej strony rozwijala się sztuka" (Odpowiedź 60, średnie, do 2 tys. mieszkańców).

- „To fantastyczny okres, który moim zdaniem ma bajeczny, niezwykły charakter, swoje tradycje i styl architektury. Zachwycal się $z$ dzieciństwa tą epoką" (Odpowiedź 35, wyższe, 100 tys. i więcej - duże miasto).

- „Uważam, że w epoce średniowiecza nastąpil bardzo duży rozwój w każdym aspekcie życia. Od sztuki, czyli nowe style architektoniczne, malarstwo, działa literackie itd. Przez rozwój edukacji, między innymi dzięki osobom duchownym. Do zakładania pierwszych «szpitali», które pomagały osobom chorym. Warto też wspomnieć, że ludzie zaczęli trudnić się też rzemiosłem i kupiectwem na wyższą skalą" (Odpowiedź 42, średnie, do 2 tys. mieszkańców).

- „Uważam, że «średniowiecze» nie było ciemne, ponieważ nastąpił wtedy rozwój nauki, szkolnictwa, za pośrednictwem Kościoła. Utworzono pierwszy Uniwersytet w Polsce (Jagielloński)" (Odpowiedź 134, średnie, 20-100 tys. - średnie miasto).

- „Uważam, że średniowiecze było nastawione na wiarę i Boga, przez co wielu artystów nie było docenianych, tworzyli anonimowo i zgodnie z kanonami Kościoła" (Odpowiedź 52, średnie, 20-100 tys. - średnie miasto).

- „Uważam, że średniowiecze jak każda epoka wniosło bardzo wiele w rozwój świata, ludzkości i kultury" (Odpowiedź 36, średnie, 20-100 tys. - średnie miasto).

- „Uważam, że średniowiecze nie bylo epoką ciemną. Wręcz odwrotnie, było epoką bardzo oświeconą" (Odpowiedź 131, średnie, 100 tys. i więcej - duże miasto).

- „W średniowieczu nadal postępowal postęp technologiczny, ale zostal przez Kościół zahamowany w dużym stopniu w porównaniu do np. starożytności" (Odpowiedź 88, średnie, do 2 tys. mieszkańców).

- „Życie w średniowieczu nie dało nikomu zbyt wysokiego wyksztalcenia, ponieważ nie rozwijano tam jakiejkolwiek edukacji, nauki" (Odpowiedź 39, średnie, do 2 tys. mieszkańców). 
OSOBY W WIEKU 25-40 LAT - 11 ODPOWIEDZI NA 19 (57,8\%)

- „Ciekawa epoka, chociaż przekłamana w mediach” (Odpowiedź 150, zasadnicze zawodowe, do 2 tys. mieszkańców).

- „Ciekawa epoka, w której powstało wiele wartościowych tez, nauk” (Odpowiedź 9, wyższe, 2-20 tys. - małe miasto).

- „Czas, w którym ważna rolę odgrywał Kościół i był stróżem prawa zarówno państwowego, jak i religijnego" (Odpowiedź 115, wyższe, 20 - 100 tys. - średnie miasto).

- „Kojarzy mi się bardzo negatywnie” (Odpowiedź 64, zasadnicze zawodowe, do 2 tys. mieszkańców).

- „Mam negatywne skojarzenia z tą epoką” (Odpowiedź 116, zasadnicze zawodowe, do 2 tys. mieszkańców).

- „Nie bylo aż tak rozwoju wiedzy, ale to z punktu widzenia dzisiejszych czasów" (Odpowiedź 117, wyższe, 20-100 tys. - średnie miasto).

- „Średniowiecze kojarzy mi się przede wszystkim z początkami państwowości polskiej: Mieszko I, Bolesław Chrobry...." (Odpowiedź 137, zasadnicze zawodowe, 20-100 tys. - średnie miasto).

- „Uważam, że średniowiecze nie było epoką ciemna. Na unikatowość tego okresu może wskazywać chociażby sztuka, która rozwinęla wiele nowych nurtów i styli. Ponadto podczas trwania tej epoki, powstało dużo uniwersytetów, filozofia przeżywała swój rozkwit, a liczne wynalazki (m.in. druk) zmieniły oblicze ziemi” (Odpowiedź 19, wyższe, 100 tys. i więcej - duże miasto).

- „Uważam, że średniowiecze to wspaniala epoka. Wbrew temu, co się mówi, nie był to czas ciemnoty. Najwięcej dogmatów czy teorii powstało właśnie wtedy. Niektórzy Ojcowie Kościoła byli geniuszami. Rozwijała się sztuka, nauka, polityka. Każdy naród mial swoje zwyczaje, swoich królów. Wtedy też wojny to było coś, walka na miecze itp. nie to co teraz. Instytucja rycerstwa, wspaniały wzór męskości i podział ról. Do dziś funkcjonuje ideał mężczyzny rycerza. Bardzo mi się podoba" (Odpowiedź 6, wyższe, 20-100 tys. - średnie miasto).

- „Wyżej zaznaczone odpowiedzi w pytanie «1» stanowią obraz promowanej w mediach wizji średniowiecza. Nie jest to jednak wizja zgodna z prawdą. Średniowiecze jest $\mathrm{w}$ mojej opinii niezwykle ważną epoką, która wyznaczyła wiele kierunków rozwoju np. w obszarze rolnictwa, szkolnictwa, medycyny. Powstało w tej epoce wiele wynalazków, które determinowały rozwój późniejszych epok. Deprecjonowanie średnio- 
wiecza w obecnych czasach ma wymiar ściśle polityczny i światopoglądowy. Zwłaszcza przez grupy radykalnie sprzeciwiające się uznaniu wkładu Kościoła w rozwój szkól, uniwersytetów, rolnictwa, medycyny itd." (Odpowiedź 26, wyższe, 20-100 tys. - średnie miasto).

- „Żałuję, że argumenty przemawiające za «nie ciemnym» średniowieczem nie są przedstawiane $w$ szkole. $O$ niektórych dowiaduję się z tej ankiety (np. młyn wodny, podkowa, produkcja papieru, weksel)" (Odpowiedź 149, gimnazjalne, 2-20 tys. - małe miasto).

\section{OSOBY W WIEKU: 40-60 LAT - 15 ODPOWIEDZI NA 34 (44,1\%)}

- „Czas rekonstrukcji kultury europejskiej po wędrówkach ludów i ich konsekwencji. Nowy porządek Europy oparty na chrześcijaństwie prowadzi do rozkwitu kultury i sztuki. Polityka jest mocno związana $\mathbf{z}$ religią, która stanowi punkt odniesienia dla wszystkich innych dziedzin życia. Ustrój feudalny i monarchia stanowią standard organizacji społeczeństwa. Spoleczeństwa stanowe i gremialne nadają mu niesamowitego kolorytu. Chęć zrozumienia świata i prawd objawionych prowadzi do powstania szkól i organizacji pierwszych Uniwersytetów. Jak każda epoka mial swoje wzloty i upadki. Krytykowane w renesansie, a jeszcze bardziej w czasie oświecenia, a później scjentyzmu obrosło w ciemna legendę" (Odpowiedź 107, wyższe, 2-20 tys. - małe miasto).

- „Każda epoka ma swoje dodatnie i ujemne aspekty, trzeba obiektywnego spojrzenia na czas i historię" (Odpowiedź 128, wyższe, 20-100 tys. - średnie miasta).

- „Kojarzy się z zacofaniem” (Odpowiedź 54, wyższe, 2-20 tys. - małe miasto).

- „Kościól determinował naukę” (Odpowiedź 15, wyższe, 20-100 tys. średnie miasto).

- „Może należałoby wysunąć postulat zmiany paradygmatu nauczania o średniowieczu w szkołach: odmitonizowania ciemnego średniowiecza" (Odpowiedź 85, wyższe, 20-100 tys. — średnie miasto).

- „Nie były takie ciemne, jak powszechnie się uważa” (Odpowiedź 30, wyższe, 100 tys. i więcej — duże miasto).

- „Obecnie zmieniła się ocena tej epoki. 30-40 lat temu średniowiecze uważano za okres ciemnoty, a obecnie dostrzega się pozytywne strony tamtych czasów" (Odpowiedź 61, wyższe, 2-20 tys. - małe miasta). 
- „Owszem, kobiety pełniły ważne role, organizowano różne typy szkół, utworzono instytucje uniwersytetu..., ale należy podkreślić, że były to działania skierowane tylko do uprzywilejowanych osób, małej, wąskiej grupy. Te przywileje i możliwości wynikały z urodzenia. Nie były czymś powszechnym, dostępnym dla wszystkich. Zdecydowana większość ludzi żyła w ciemnym średniowieczu" (Odpowiedź 97, wyższe, 100 tys. i więcej - duże miasta).

- „Średniowiecze było bogate i twórcze, choć miało swoje niedostatki jak każda epoka" (Odpowiedź 16, wyższe, 100 tys. i więcej - duże miasto).

- „Średniowiecze jest wielką epoką, która zaznaczyła się wypracowaniem tego wszystkiego, czym do dzisiaj żyjemy, nawet jeśli dokonuje się to w formie mocno sekularyzowanej. Jeśli bylaby to epoka «ciemna», to dlaczego poświęca się jej tyle publikacji? Moim zdaniem jest to kluczowy argument za «jasnością» tej epoki, z którego się zupełnie nie korzysta. W większości dobrych księgarń na świecie ma osobne regały. Osobiście fascynuje mnie w średniowieczu wielkość doświadczeń duchowych i intelektualnych" (Odpowiedź 127, wyższe, 20-100 tys. średnie miasto).

- „Średniowiecze, ze szkoły kojarzy mi się z biedą, zacofaniem, niskim poziomem życia, czyli «ciemnotą»" (Odpowiedź 57, wyższe, 100 tys. i więcej — duże miasto).

- „Uważam, że było «ciemne»” (Odpowiedź 58, wyższe, 100 tys. i więcej — duże miasto).

- „W średniowieczu powstało i rozwinęlo się nasze państwo” (Odpowiedź 29, wyższe, 100 tys. i więcej — duże miasto).

- „Warto rozprawić się z etykietą «ciemnego» średniowiecza. To cudowna epoka rozwoju, kreacji artystycznych i rozwoju nauki. Warto upowszechniać badania Le Goffa, Borowskiego, Michałowskiej czy Curtiusa" (Odpowiedź 31, wyższe, 20-100 tys. - średnie miasto).

\section{OSOBY POWYŻEJ 60 LAT: 11 ODPOWIEDZI NA 20 (55,0\%)}

- „To dziwna epoka, ale jak w każdej też są dobre strony” (Odpowiedź 135, wyższe, 20-100 tys. - średnie miasta).

- „Było święte” (Odpowiedź 130, wyższe, do 2 tys. mieszkańców).

- „Cenię średniowiecze za to, że glosiło teocentryzm. Jasno oddzielano dobro od zła. Bardziej niż materialne ceniono dobra duchowe. Cenię 
za wielkich teologów: np. św. Tomasz z Akwinu. Pięć dróg Tomaszowych to wciąż podwaliny mojego światopoglądu. Doceniam rolę Kościoła w średniowieczu: jego dążenie do stworzenia kultury o uniwersalnym charakterze, kultury lączącej chrześcijan wielu krajów. Do osiągnięcia tego celu przyczyniła się między innymi nauka religii, oparta na Piśmie św., język laciński i tradycja antyczna, które Kościół przeszczepiał w różnych postaciach i dziedzinach kultury" (Odpowiedź 108, wyższe, 2-20 tys. - małe miasto).

- „Gratulacje dla osoby, która podjęła te badania. Ciekawa inicjatywa badawcza" (Odpowiedź 95, wyższe, 20-100 tys. — średnie miasto).

- „Miało duże osiągnięcia w filozofii, sztuce” (Odpowiedź 102, wyższe, 2-20 tys. - małe miasto).

- „Przede wszystkim średniowiecze obejmujące co najmniej kilkaset lat nie jest jednorodne, stąd stereotypowa opinia o nim świadczy raczej o «zacofaniu» tego, kto lansuje takie poglądy. To epoka niezwykle twórcza kulturowo, której nie można oceniać według współczesnych standardów życia, kultury, techniki. Uwzględniając różnorodne uwarunkowania tamtych czasów, można jedynie podziwiać geniusz ludzi, którzy żyli w tamtych czasach i obserwować, jak niezwykle kulturotwórczą funkcję spelniało chrześcijaństwo" (Odpowiedź 105, wyższe, 100 tys. i więcej — duże miasto).

- „Przeraża mnie obraz średniowiecza” (Odpowiedź 94, wyższe, 20-100 tys. - średnie miasto).

- „Średniowiecze było ostoją dla wartości chrześcijańskich i ogólnoludzkich, które krzewilo po odcięciu się od okresu pogańskiego w Polsce. Wnosiło w życie humanizm chrześcijański. Wniosło nas na wyższy stopień kultury (dzięki chrześcijaństwu). Bóg był w centrum wizji świata i życia, dzięki czemu fundamentalne wartości mogły się rozwijać, wśród nich patriotyzm i poczucie obywatelskiego obowiązku. Stawiając Boga na pierwszym miejscu, gwarantowało ustawienie wlaściwej hierarchii wartości (czego tak bardzo teraz brak). To właśnie w średniowieczu tworzył wybitny myśliciel, teolog i filozof, św. Tomasz z Akwinu, a stworzony przez niego system naukowy jest aktualny do dziś i wciąż stanowi podstawę dla wielu rozważań naukowych (w tym teologicznych). Na ten okres przypada rozwój szkół, uniwersytetów, bibliotek. To średniowiecze szczyci się również stworzeniem stylu romańskiego i gotyckiego $w$ sztuce sakralnej, jak też wyna- 
lezieniem druku. To z tego okresu zatem pochodzą pierwsze księgi spisane po polsku, jak kazania, psałterze i zabytek literatury religijnej, pieśń «Bogurodzica», czy wreszcie kroniki: Galla Anonima, Wincentego Kadłubka i Jana Długosza. W tym okresie dokonano też wielu wynalazków przedmiotów przydatnych w różnych sferach życia i pracy. Nad ciemnymi stronami tego okresu (które można przecież odnaleźć w każdym) przeważały właśnie jasne, wspaniałe dokonania i światla myśll" (Odpowiedź 101, wyższe, 2-20 tys. - małe miasto).

- „Średniowiecze to rozwój samorządności miast (wolne miasta), rozwój gospodarczy (reformy benedyktynów i cystersów), rozwój nauki i sztuki dzięki upowszechnieniu uniwersytetów" (Odpowiedź 113, wyższe, 100 tys. i więcej — duże miasto).

- „Średniowiecze, to okres rozwoju cywilizacyjnego i nauki” (Odpowiedź 7, średnie, 2-20 tys. - małe miasto).

- „Znakomita epoka, z wielkimi umysłami, których dorobek jest podstawą współczesnych osiągnięć”" (Odpowiedź 112, wyższe, 100 tys. i więcej — duże miasto).

\section{WNIOSKI I DYSKUSJA}

Przedmiotem prezentowanych badań było określenie stanu wiedzy na temat kultury średniowiecznej i współczesnego postrzegania tejże epoki. Analiza poznawcza opinii współczesnego społeczeństwa na temat mitu „ciemnego” średniowiecza, analiza porównawcza społecznych determinantów postrzegania tejże epoki oraz ich źródeł (społecznych, kulturowych, edukacyjnych i medialnych) pozwoliła na częściowe potwierdzenie hipotezy badawczej, zakładającej funkcjonowanie w świadomości społecznej współczesnego człowieka mitu „ciemnego" średniowiecza.

W przeprowadzonych badaniach respondenci łącznie wyrazili 1250 opinii, w tym $583^{19}$ potwierdzających mit „ciemnego" średniowiecza oraz $667^{20}$ tenże mit obalających.

\footnotetext{
${ }^{19}$ Wśród 583 opinii, znajdują się wypowiedzi własne respondentów, które obalają mit „ciemnego" średniowiecza: 7.

${ }^{20}$ Wśród 667 opinii, znajdują się wypowiedzi własne respondentów, które potwierdzają mit „ciemnego" średniowiecza: 5.
} 
Tabela 14. Analiza porównawcza opinii potwierdzających i obalających mit „ciemnego" średniowiecza uwzględniająca kryterium wiekowe

\begin{tabular}{|c|c|c|c|c|c|c|}
\hline \multirow{2}{*}{ L.p. } & \multirow{2}{*}{ Wiek } & Liczba respondentów & \multicolumn{4}{|c|}{ Liczba opinii } \\
\cline { 3 - 7 } & & & \multicolumn{2}{|c|}{$\begin{array}{c}\text { Argumenty } \\
\text { potwierdzające mit }\end{array}$} & \multicolumn{2}{|c|}{$\begin{array}{c}\text { Argumenty } \\
\text { obalające mit }\end{array}$} \\
\hline & & & L & S & L & S \\
\hline 1. & mniej niż 19 lat & 26 & 107 & 4,12 & 95 & 3,65 \\
\hline 2. & $19-25$ & 51 & 212 & 4,16 & 216 & 4,23 \\
\hline 3. & $25-40$ & 19 & 85 & 3,68 & 70 & 3,68 \\
\hline 4. & $40-60$ & 34 & 116 & 3,30 & 174 & 5,11 \\
\hline 5. & powyżej 60 lat & 20 & 63 & 3,15 & 112 & 5,60 \\
\hline tącznie & & $\mathbf{1 5 0}$ & $\mathbf{5 8 3 ( - 7 )}$ & $\mathbf{3 , 8 4}$ & $\mathbf{6 6 7}(-\mathbf{5})$ & $\mathbf{4 , 4 5}$ \\
\hline
\end{tabular}

Źródło: opracowanie własne na podstawie badań ankietowych

Legenda: L — liczba opinii, Ś — średnia liczba opinii przypadająca na 1 osobę

Chociaż zgromadzone dane (tabela 14) nie pozwalają jednoznacznie potwierdzić hipotezy badawczej, zakładającej, że w świadomości społecznej współczesnego człowieka funkcjonuje mit „,ciemnego” średniowiecza, to należy zauważyć, że ten wniosek nie odnosi się w jednakowym stopniu do wszystkich grup wiekowych. Ponadto wyjątek stanowią respondenci poniżej 19 roku życia. Liczba wyrażonych opinii potwierdzających mit o „ciemnym” średniowieczu przewyższa liczbę opinii obalających analizowany mit (107 wobec 95 osób; 4,12 wobec 3,65 opinii/argumentów). Natomiast badani z przedziału wiekowego 25-40 lat wyrazili jednakową liczbę argumentów przypadających na 1 osobę $(3,68)$ zarówno za „ciemnym” średniowieczem, jak i zaprzeczających temu mitowi.

$\mathrm{Na}$ pytanie o argumenty potwierdzające mit „ciemnego” średniowiecza odpowiedzi udzieliło 144 respondentów spośród 150, którzy łącznie podali 583 opinii (tabela 4). Głównym argumentem, w opinii większości badanych (59\%), przemawiającym za negatywnym postrzeganiem epoki średniowiecza była wiedza, że wierzono wówczas w zabobony, horoskopy czy organizowano polowania na czarownice. Kolejnym - stosowanie kar cielesnych, zaniedbywanie medycyny oraz poniżanie roli i znaczenia kobiet $-43,1 \%$ badanych. Nieco mniej, bo $38,9 \%$ ankietowanych, wskazało na panowanie inkwizycji i okrucieństwa. 
Z uzyskanych danych wynika, że najwięcej argumentów potwierdzających mit „ciemnego” średniowiecza podali respondenci:

- w wieku 25-40 (uśredniony wynik dla 1 osoby: 4,47), natomiast najmniej osoby powyżej 60 lat (uśredniony wynik dla 1 osoby: 3,15 );

- posiadający wykształcenie zasadnicze zawodowe; uśredniony wynik dla 1 osoby wynosi 5,28; natomiast najmniej - osoby z wykształceniem średnim; co drugi badany: 0,42 .

- Miejsce zamieszkania respondentów minimalnie różnicuje ich opinie. Co najmniej połowa ankietowanych reprezentujących wszystkie analizowane grupy wskazała na odpowiedź: wierzono $w$ zabobony (polowania na czarownice).

Analogicznie na pytanie o argumenty obalające mit „ciemnego” średniowiecza odpowiedzi udzieliło 145 respondentów spośród 150, którzy łącznie wskazali 667 odpowiedzi (tabela 9). Wymownym powodem, w opinii większości badanych (59,3\%), przemawiającym za wyjątkowością średniowiecza był jego wkład w rozwój architektury, malarstwa i muzyki. Należy zauważyć, że ten wskaźnik jest porównywalny z liczbą osób uznających mit „ciemnego" średniowiecza (59,0\%). Kolejnymi argumentami obalającym analizowany mit jest utworzeniu instytucji uniwersytetu $(52,4 \%)$ oraz liczne wynalazki $(43,4 \%)$.

Z uzyskanych danych wynika, że najwięcej argumentów obalających mit „ciemnego” średniowiecza wskazali respondenci:

- powyżej 60 roku życia $(5,6)$, natomiast najmniej najmłodsi uczestnicy badań — osoby poniżej 19 lat: 3,65; kolejno — 40-60 lat: 5,11; 1925 lat: 4,23; 25-40 lat: 3,68;

- posiadający wykształcenie wyższe; uśredniony wynik dla 1 osoby wynosi: 5,58; natomiast najmniej osoby $\mathrm{z}$ wykształceniem zasadniczym zawodowym i podstawowym; średnio mniej niż trzy argumenty $(2,85$ i 2,91$)$. Porównywalny jest wynik dla osób z wykształceniem średnim i gimnazjalnym $(3,82$ i 3,81) - mniej niż cztery argumenty.

- Miejsca zamieszkania respondentów w minimalnym stopniu polaryzuje ich opinie w kwestii utworzenia nowego stylu w architekturze, malarstwie i muzyce. Różnica procentowa oscyluje wokół 10 punktów procentowych (od 53\% — osoby zamieszkujące małe miejscowości, do $63 \%$ - mieszkańcy wielkich miast). Natomiast najbardziej w kwestii zakładania szpitali i sierocińców (różnica 28p.p.); od 22\% - badani z miejscowości do 2 tys. mieszkańców, do 50\% — respondenci z miast powyżej 100 tys. mieszkańców. 
Pierwsza hipoteza szczegółowa, zakładająca, że wiek respondentów nie różnicuje ich opinii na temat średniowiecza, została obalona. $Z$ przeprowadzonych badań wynika, że wraz z wiekiem systematycznie zmniejsza się liczba opinii potwierdzających analizowany mit (z 4,12 — osoby poniżej 19 lat, do 3,15 - osoby powyżej 60 roku życia, przy średnim wyniku 3,84 opinii przypadających na 1 badaną osobę). Przeciwną tendencję zaobserwowano, analizując opinie obalające mit „ciemnego" średniowiecza: wraz z wiekiem wzrasta średnia liczba opinii potwierdzających epokowość średniowiecza (z 3,65 - osoby poniżej 19 lat, do 5.60 - osoby powyżej 60 roku życia, przy uśrednionym wyniku 4,45). Wyjątek stanowią osoby w wieku 19-25 lat.

Druga hipoteza szczegółowa: „opinie o epoce średniowiecza determinuje wykształcenie respondentów. Im wyższe wykształcenie respondentów, tym lepsza znajomość epoki implikująca jego korzystniejsze oceny" została częściowo potwierdzona. Ankietowani posiadający wyższe wykształcenie wymieniają dwa razy więcej pozytywnych opinii na temat epoki średniowiecza niż respondenci deklarujący najniższe wykształcenie. Zależność ta jednak nie wzrasta systematycznie. Analogicznie w przypadku opinii/argumentów potwierdzających mit o „ciemnym” średniowieczu. Poziom wykształcenia badanych nie implikuje jednoznacznych ocen epoki.

Tabela 15. Analiza porównawcza opinii potwierdzających i obalających mit „ciemnego" średniowiecza uwzględniająca wykształcenie respondentów

\begin{tabular}{|c|l|c|c|c|c|c|}
\hline \multirow{2}{*}{ L.p. } & \multirow{2}{*}{ Wiek } & Liczba respondentów & \multicolumn{4}{|c|}{ Liczba opinii } \\
\cline { 3 - 7 } & & & \multicolumn{2}{|c|}{$\begin{array}{c}\text { Argumenty } \\
\text { potwierdzające mit }\end{array}$} & \multicolumn{2}{|c|}{$\begin{array}{c}\text { Argumenty } \\
\text { obalające mit }\end{array}$} \\
\hline & & & L & Ś & L & S \\
\hline 1. & podstawowe & 12 & 49 & 4,08 & 35 & 2,91 \\
\hline 2. & gimnazjalne & 11 & 42 & 3,81 & 42 & 3,81 \\
\hline 3. & zasadnicze zawodowe & 7 & 37 & 5,28 & 20 & 2,85 \\
\hline 4. & średnie & 57 & 24 & 0,42 & 218 & 3,82 \\
\hline 5. & wyższe & 63 & 212 & 3,36 & 352 & 5,58 \\
\hline tącznie & & $\mathbf{1 5 0}$ & $\mathbf{5 8 3 ( - 7 )}$ & $\mathbf{3 , 3 9}$ & $\mathbf{6 6 7}(\mathbf{- 5})$ & $\mathbf{3 , 7 9}$ \\
\hline
\end{tabular}

Źródło: opracowanie własne na podstawie badań ankietowych

Legenda: L — liczba opinii, Ś — średnia liczba opinii przypadająca na 1 osobę 
Trzecia hipoteza szczegółowa, zakładająca, że głównym źródłem informacji o średniowieczu są podręczniki, została potwierdzona. Na to źródło wskazało 104 respondentów $(72,7 \%)$.

\section{KONKLUZJA}

Przeprowadzone badania ankietowe i analizy wypowiedzi mogą stać się podstawą dla wielu interesujących analiz i wniosków. $Z$ jednej strony możemy stwierdzić, że ich wynik jest pozytywny, ponieważ procentowo, chociaż z niewielką przewagą, średniowiecze otrzymało przychylną ocenę. Z drugiej jednak strony mit o „ciemnym” średniowieczu utrzymuje się nadal, zwłaszcza wśród ludzi młodych. Co znamienne, powołują się oni na wiedzę (a raczej jej brak) o epoce średniowiecza zdobytą $w$ szkole od nauczycieli i z podręczników lub z mediów. Warto zatem zadać pytanie: Jaki obraz tej epoki lansują polska szkoła oraz media? Drugi interesujący aspekt badań pokazuje, że ci, którzy dysponują sporą wiedzą o średniowieczu i pozytywnie go oceniają, znają dorobek tej epoki najczęściej w sferze sztuki (styl romański, gotycki, malarstwo), natomiast prawie nieobecny w ich świadomości jest najistotniejszy wymiar dziedzictwa wieków średnich, jakim jest kultura duchowa i religia. Tymczasem chrześcijańska duchowość była jednym z „najważniejszych czynników jedności kulturowej Europy”21. Ten właśnie wymiar stanowi rdzeń każdej kultury i jest miernikiem jej spójności i żywotności, wyznacza bowiem ostateczny cel i sens ludzkiej egzystencji. Wobec powyższego należy zadać bardziej zasadnicze pytanie: Czy współczesny człowiek w ogóle pyta o sens życia, o sens świata? Czy ma świadomość jego potrzeby?

Analitycy i komentatorzy współczesnej kultury zachodniej są zgodni co do tego, że znalazła się ona w poważnym, głębokim kryzysie. Mówiąc o letargu, w jaki zapadają się obywatele Europy, pokazują, czym taki stan grozi: podczas gdy całe społeczeństwa oddają się egzystencjalnej drzemce (myśl europejska przestała być żywa, a demokracja stała się abstrakcyjna jak europejskie wartości), inni uświadamiają sobie siłę idei i terrorem narzucają własne porządki sprzeczne $\mathrm{z}$ tymi, które stworzyły wspaniałą zachodnią cywilizację. Tę sytuację trafnie oddaje konstatacja „Bóg umarł, ale Allach żyje”22.

\footnotetext{
${ }^{21}$ Jerzy KŁoczowski, Europa. Chrześcijańskie korzenie (Warszawa: Wydawnictwo Piotra Marczuka Stentor, 2004), 121.

${ }^{22}$ Zob. Jan Krasicki, Po „śmierci Boga”. Eseje eschatologiczne (Kraków: Homini, 2011), 33.
} 
Czym może być — pyta francuska filozof Chantal Delsol — ziejąca luka w duszach poszukujących wartości, lecz pozbawionych busoli? Brak busoli to najgroźniejszy w skutkach relatywizm, a więc odrzucenie prawdy jako stałej, uniwersalnej, obiektywnej wartości, a za tym idzie - odrzucenie tego wszystkiego, co stanowi fundament życia społecznego: „A gdy kwestionowana jest skała, społeczeństwo pogrąża się w nihilizmie. Katastrofa powodowana przez wyzwolenie osiąga swój punkt szczytowy, stając się bardziej katastrofą niż wyzwoleniem — nie sposób bowiem wyzwolić się od kamieni węgielnych",23.

Krytykuje się średniowiecze za teocentryzm, a wychwala nowożytność za antropocentryzm i humanizm. Przenikliwy krytyk kultury europejskiej Fryderyk Nietzsche, ogłosiwszy „śmierć Boga”, zanim obwieścił wiedzę radosną o nadczłowieku, pokazał jednocześnie konsekwencje ateizmu i nieobecności Boga w świecie jako tego, który jest gwarantem kosmicznego ładu i moralnego porządku: „Czy wypiliśmy morze? Czy więc stoimy jeszcze na nogach? Czy nie przewracamy się ciągle? Niejako w dół, w tył, na bok, na wszystkie strony? [...] I straciliśmy wszelką ciężkość, bo nie ma już dla nas ani góry, ani dołu?"24. Poczucie chaosu, zagubienie, samotność i utrata jakiejkolwiek podstawy wartości, jakiegokolwiek punktu odniesienia to skutki uwolnienia się od Boga. Nie chodzi tu o metafizyczne dowody na jego nieistnienie, jest to raczej wyrażenie sposobu egzystencji współczesnych Europejczyków, atrofia wartości chrześcijańskich i życie tak, jakby Bóg nie istniał. „Śmierć Boga” tak rozumiana nie oznacza całkowitego ateizmu, niewierzenia w nic, ale raczej wierzenie w cokolwiek. Jak stwierdził Leszek Kołakowski, na tych, którzy odrzucili jedynego Boga, „spada deszcz nowych bogów" - i sam wyraża lęk, ostrzegając przed takimi bogami ${ }^{25}$.

Można zapytać, co z drugą częścią nietzscheańskiej proklamacji wiedzy radosnej o nadczłowieku, który miał zastąpić Boga, sam nim się stać. Jak dotąd mamy jedynie karykaturalne wcielenie idei nadczłowieka. Niemcy, siebie obwoławszy nadludźmi, wytworzyli hordy oprawców i wywołali II wojnę

\footnotetext{
${ }^{23}$ Delsol, Nienawiść, s. 92.

${ }^{24}$ Cyt. za: Zbigniew KazimierczaK, „U źródeł automitycznej religijności Nietzschego”, w: Ateny, Rzym, Bizancjum. Mity Śródziemnomorza w kulturze XIX i XX wieku, red. Jarosław Ławski i Krzysztof Korotkich (Białystok: Wydawnictwo Uniwersyteckie Trans Humana, 2008), 77-78.

${ }^{25}$ „Po stuleciach wzrostu oświecenia budzimy się nagle pośród zamętu umysłowego i moralnego; coraz większym lękiem napawa nas widok świata, który zaprzepaścił swoje dziedzictwo religijne i nasz lęk jest dobrze usprawiedliwiony. Miejsce rozwianych mitów zajmuje częściej nie oświecona racjonalność, lecz jej przerażające świeckie karykatury i substytuty”. Cyt. za: KRASICKI, Po ,śmierci Boga”, 35.
} 
światową, która prześcignęła $\mathrm{w}$ barbarzyństwie wszystkie poprzednie wieki razem wzięte. Natomiast druga odsłona dwudziestowiecznego barbarzyństwa to monstrualny despotyzm komunizmu, który terrorem wprowadzając komunistyczny „raj”, wymordował w męczarniach dziesiątki milionów ludzi. Zamiast zapowiadanego ubóstwienia nastąpiło raczej „ubestwienie”, od „śmierci Boga” do „śmierci człowieka” droga okazała się bliska.

Może zatem nie mamy innego wyjścia, jak pójść za wizją Jacquesa Maritaina, który pragnął dla Europy i świata nowego ładu chrześcijańskiego, rzec by można „nowego średniowiecza”, o którym pisał Mikołaj Bierdiajew. Może to jedyny ratunek - powrót do wartości broniących człowieka przed nim samym, które nie pochodzą z ludzkiego ustanowienia, a jako takie muszą mieć ugruntowanie w Transcendencji, w woli wyższej od samego człowieka?

\section{BIBLIOGRAFIA}

Copleston, Frederick. Historia filozofii, t. 6: Od Wolffa do Kanta. Przeł. Jerzy Łoziński. Warszawa: Instytut Wydawniczy Pax, 2005.

Dawson, Christopher. Szkice o kulturze średniowiecznej. Przeł. Jan Sulowski. Warszawa: Instytut Wydawniczy Pax, 1966.

DelPeCh, Thérèse. Powrót barbarzyństwa w XXI wieku. Przeł. Wiktor Dłuski. Warszawa: Media Lazar Nadir, 2008.

Delsol, Chantal. Nienawiść do świata. Totalitaryzmy i ponowoczesność. Przeł. Marek Chojnacki. Warszawa: Instytut Wydawniczy Pax, 2017.

GÉNicot, Léopold. Powstaje nowy świat. Przeł. Jan Stanisław Łoś. Warszawa: Ossolineum, 1964.

Le Goff, Jacques. Inteligencja w wiekach średnich. Przeł. Eligia Bąkowska. Warszawa: Oficyna Wydawnicza Volumen, Dom Wydawniczy Bellona, 1997.

GórnY, Grzegorz. „Pożar Notre Dame: znak do odczytania”. „Niedziela” (ogólnopolska) 2019, nr 17. Niedziela.pl. Dostęp 22 lutego 2021. https://www.niedziela.pl/artykul/142506/nd/ Pozar-Notre-Dame-znak-do-odczytania.

Jan Pawee II. Pamięć i tożsamość. Rozmowy na przełomie tysiq̨cleci. Kraków: Wydawnictwo Znak, 2005.

KaZimierczak, Zbigniew. „U źródeł automitycznej religijności Nietzschego”. W: Ateny, Rzym, Bizancjum. Mity Śródziemnomorza w kulturze XIX i XX wieku, red. Jarosław Ławski i Krzysztof Korotkich. Antyk Romantyków, 75-80. Białystok: Wydawnictwo Uniwersyteckie Trans Humana, 2008.

Krasicki, Jan. Po „śmierci Boga”. Eseje eschatologiczne. Kraków: Homini, 2011.

SAInt-EXuPÉry, Antoine de. Maty Książę. Przeł. Jan Szwykowski. Warszawa: Instytut Wydawniczy Pax, 1971.

SCRUTOn, Roger. Pożytki z pesymizmu i niebezpieczeństwa falszywej nadziei. Przeł. Tomasz Bieroń. Poznań: Zysk i S-ka, 2012. 
Tatarkiewicz, Władysław. Historia filozofii, t. 1: Filozofia starożytna i średniowieczna. Warszawa: Państwowe Wydawnictwo Naukowe, 1970

Wielgus, Stanisław. Z badań nad średniowieczem. Lublin: Redakcja Wydawnictw KUL, 1995.

\author{
MIT „CIEMNEGO” ŚREDNIOWIECZA \\ WE WSPÓŁCZESNYM DYSKURSIE SPOŁECZNYM
}

\title{
Streszczenie
}

W refleksji na temat europejskiej tożsamości kulturowej odwołujemy się do trzech jej źródeł: filozofii greckiej, prawa rzymskiego i chrześcijaństwa. Jeśli chodzi o trzecie źródło - chrześcijaństwo, to stanowi ono serce kultury średniowiecznej, która tworzyła Europę opartą na ewangelicznych wartościach, takich jak: prawda, miłość, współczucie, pokora, równość, braterstwo, wolność, godność osoby ludzkiej. Mimo to epoka średniowieczna, jak żadna inna, jest ciągle deprecjonowana i ignorowana. Mit „ciemnego” średniowiecza, wylansowany w odrodzeniu, przekazywany i pogłębiany w kolejnych epokach, utrwalił się i zajął stałe miejsce w potocznej świadomości. Mediewiści stawiają sobie pytanie, dlaczego tak się dzieje. Ciągle słyszymy w powszechnym dyskursie epitet o „ciemnym” średniowieczu. Celem prezentowanych badań było określenie stanu wiedzy na temat kultury średniowiecznej, a także współczesnego postrzegania tejże epoki. Wyniki badań ankietowych, mających na celu zbadanie obecności mitu „ciemnego” średniowiecza w świadomości dzisiejszego społeczeństwa, mogą stanowić przyczynek do dalszych badań nad tym zjawiskiem. Doniosłość tej problematyki leży w tym, że odzwierciedla ona odniesienie współczesnego człowieka do wartości, jakie reprezentuje kultura średniowieczna.

Słowa kluczowe: mit; „ciemne” średniowiecze; kultura; wartość; rozum; wolność; kryzys kulturowy; analiza ilościowa i jakościowa; badania ankietowe; sondaż diagnostyczny.

\section{THE MYTH OF THE “DARK” MIDDLE AGES IN THE CONTEMPORARY SOCIAL DISCOURSE}

\section{Sum mary}

In our reflection on Europe's cultural identity, we will refer to its three sources: Greek philosophy, Roman law, and Christianity. The third source, Christianity, is considered to be the heart of medieval culture, which created Europe based on evangelical values such as truth, love, compassion, humility, equality, fraternity, freedom, and human dignity. Nevertheless, the medieval era is still being depreciated and ignored like no other. The myth of the "dark" Middle Ages, promoted in the Renaissance, passed on and deepened in subsequent eras, became permanent and has a lasting place in the common consciousness. Medievalists ask: "why is this happening?" In popular discourse, we constantly hear the epithet about the "dark" Middle Ages. The presented research aims to determine the state of knowledge about medieval culture as well as contemporary people's perceptions of that era. The results of surveys aimed at examining the presence of the myth about the "dark" Middle Ages in the awareness of contemporary society may be a contribution to further research on this phenomenon. The importance of this problem lies in the fact that it reflects contemporary man's relationship to the values represented by medieval culture.

Key words: myth; "dark" Middle Ages; culture; value; reason; freedom; cultural crisis; quantitative and qualitative analysis; questionnaire research survey; diagnostic survey. 